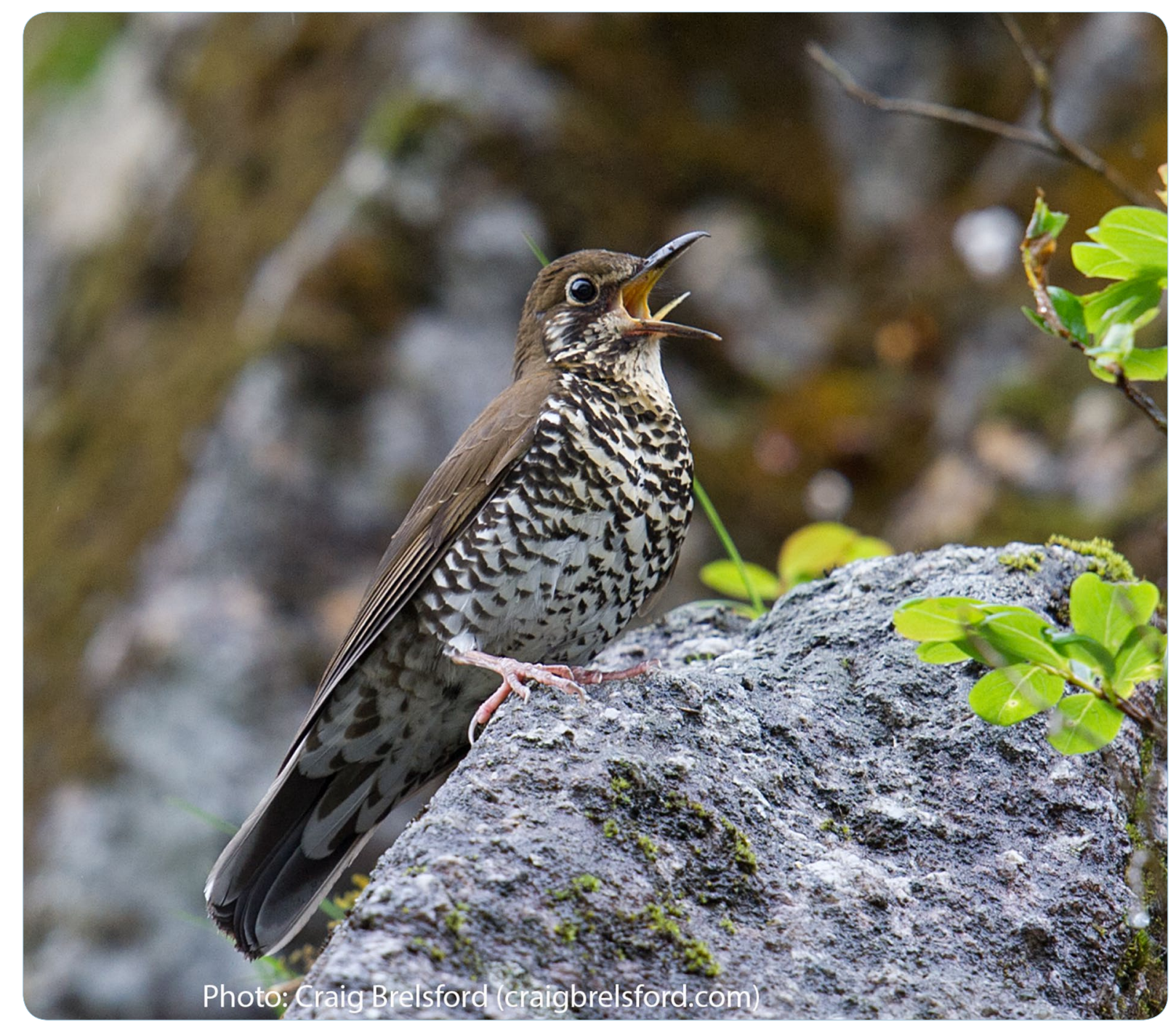

\title{
Integrative taxonomy of the Plain-backed Thrush (Zoothera mollissima) complex (Aves, Turdidae) reveals cryptic species, including a new species
}

Alström et al. 


\title{
Integrative taxonomy of the Plain-backed Thrush (Zoothera mollissima) complex (Aves, Turdidae) reveals cryptic species, including a new species
}

Per Alström ${ }^{1,2,3^{*}} \mathbb{D}$, Pamela C. Rasmussen ${ }^{4,5}$, Chao Zhao ${ }^{6}$, Jingzi Xu7 ${ }^{7}$, Shashank Dalvi ${ }^{8}$, Tianlong Cai ${ }^{2,9}$, Yuyan Guan ${ }^{2,9}$, Ruiying Zhang ${ }^{2}$, Mikhail V. Kalyakin ${ }^{10}$, Fumin Lei ${ }^{2}$ and Urban Olsson ${ }^{11}$

\begin{abstract}
Background: The Plain-backed Thrush Zoothera mollissima breeds in the Himalayas and mountains of central China. It was long considered conspecific with the Long-tailed Thrush Zoothera dixoni, until these were shown to be broadly sympatric.

Methods: We revise the Z. mollissima-Z. dixoni complex by integrating morphological, acoustic, genetic (two mitochondrial and two nuclear markers), ecological and distributional datasets.

Results: In earlier field observations, we noted two very different song types of "Plain-backed"Thrush segregated by breeding habitat and elevation. Further integrative analyses congruently identify three groups: an alpine breeder in the Himalayas and Sichuan, China ("Alpine Thrush"); a forest breeder in the eastern Himalayas and northwest Yunnan (at least), China ("Himalayan Forest Thrush"); and a forest breeder in central Sichuan ("Sichuan Forest Thrush"). Alpine and Himalayan Forest Thrushes are broadly sympatric, but segregated by habitat and altitude, and the same is probably true also for Alpine and Sichuan Forest Thrushes. These three groups differ markedly in morphology and songs. In addition, DNA sequence data from three non-breeding specimens from Yunnan indicate that yet another lineage exists ("Yunnan Thrush"). However, we find no consistent morphological differences from Alpine Thrush, and its breeding range is unknown. Molecular phylogenetic analyses suggest that all four groups diverged at least a few million years ago, and identify Alpine Thrush and the putative "Yunnan Thrush" as sisters, and the two forest taxa as sisters. Cytochrome $b$ divergences among the four Z. mollissima sensu lato (s.l.) clades are similar to those between any of them and $Z$. dixoni, and exceed that between the two congeneric outgroup species. We lectotypify the name Oreocincla rostrata Hodgson, 1845 with the Z. mollissima sensu stricto (s.s.) specimen long considered its type. No available name unambiguously pertains to the Himalayan Forest Thrush.
\end{abstract}

Conclusions: The Plain-backed Thrush Z. mollissima s.l. comprises at least three species: Alpine Thrush Z. mollissima s.S., with a widespread alpine breeding distribution; Sichuan Forest Thrush Z. griseiceps, breeding in central Sichuan forests; and Himalayan Forest Thrush, breeding in the eastern Himalayas and northwest Yunnan (at least), which is described herein as a new species. "Yunnan Thrush" requires further study.

Keywords: Systematics, Morphology, Bioacoustics, Altitudinal distributions, Genetic distances, Undescribed taxa, Zoothera dixoni, Lectotypification, Holotype

\footnotetext{
*Correspondence: per.alstrom@ebc.uu.se

${ }^{3}$ Swedish Species Information Centre, Swedish University of Agricultural

Sciences, Box 7007, 75007 Uppsala, Sweden

Full list of author information is available at the end of the article

The original version of this article was replaced with the current version at the request of the journal's editors. Amendments have been made to the non-scientific content of the article.
} 


\section{Background}

The thrush genus Zoothera (Turdidae) previously comprised species in Africa, Asia and North America (Ripley 1964). However, molecular analyses (Klicka et al. 2005; Nylander et al. 2008; Voelker and Outlaw 2008) showed Ripley's (1964) Zoothera to be an unnatural grouping, and Zoothera is now restricted to 18 extant and one recently extinct species, which are patchily distributed from Siberia to Sri Lanka, and eastward through Indonesia to Australia and various western Pacific islands (Collar 2005; Dickinson and Christidis 2014; Gill and Donsker 2015). One of the species, Geomalia Z. heinrichi, was previously placed in the monotypic genus Geomalia, with uncertain affinities, but was recently suggested to be nested within Zoothera (Olsson and Alström 2013).

The Plain-backed Thrush $Z$. mollissima breeds throughout the Himalayas and into central China (Collar 2005; Dickinson and Christidis 2014; Gill and Donsker 2015). It breeds at high elevation, in forest as well as above the tree limit, and descends to lower elevation in winter (Clement et al. 2000; Collar 2005). Three subspecies are now generally recognized: $Z$. m. whiteheadi (Stuart Baker, 1913) from Pakistan to west-central Nepal, Z. m. mollissima (Blyth, 1842) in the rest of the Himalayas, and Z. m. griseiceps (Delacour, 1930) in southcentral China (Sichuan, Yunnan) and northern Vietnam (Tonkin); several other names are in synonymy. The Long-tailed Thrush $Z$. dixoni (Seebohm, 1881) was generally considered conspecific with Zoothera mollissima, based on Sharpe's comments in Seebohm et al.s (1898) posthumously published monograph on thrushes, until Delacour (1930; with input from N. Kinnear) showed that there were fairly consistent morphological differences. These were further verified by Vaurie (1955), who also showed that $Z$. mollissima and $Z$. dixoni were sympatric throughout most of their breeding ranges. Molecular phylogenetic analyses have confirmed the close relationship between $Z$. dixoni and $Z$. mollissima (Olsson and Alström 2013; previously suggested also by Klicka et al. 2005 , but using a misidentified sample of $Z$. dixoni).

The present study was initiated in June 2009, when P.A. and S.D. discovered that there were two species of "Plainbacked Thrush" breeding in sympatry in the eastern Himalayas. These were completely segregated by elevation and habitat, one occurring in mostly coniferous forest up to the upper tree limit (3430-4200 m a.s.l.) and the other in alpine habitats above the tree limit $(>4200 \mathrm{~m})$. Their songs were strikingly different, although no definite morphological differences were detected in the field. One of us (P.A.) had previously heard the song of "Plain-backed Thrush" in mountain forests in Sichuan Province, China, and remembered this as being reminiscent of the Himalayan forest species. The two Himalayan song types had both previously been attributed to $Z$. mollissima by various recordists, and they were thus described as alternative songs of this species (Rasmussen and Anderton 2005).

We here revise the taxonomy of the $Z$. mollissima-Z. dixoni complex based on analyses of morphology, songs, two mitochondrial genes and two nuclear introns, ecology and geographical distributions. As part of the revision, we describe a new species in the complex.

\section{Methods}

We analyzed DNA from type specimens or (in the case of Z. $m$. whiteheadi) specimens from the type series of four nominal taxa that have been synonymised with one or another $Z$. mollissima subspecies. The type specimen of $Z$. $m$. mollissima (Blyth, 1842) may have been lost, but based on the original description, we conclude that Blyth's name mollissima, as well as all other taxonomic names previously used in this complex, except griseiceps, are either unavailable or refer to the same taxon, namely the one that we found breeding above the tree limit in the eastern Himalayas in June 2009. We refer to this taxon as Alpine Thrush; to the one we first found breeding in forests in the Himalayas as Himalayan Forest Thrush; and to the one breeding in forests in Sichuan Province, China as Sichuan Forest Thrush. We describe the Himalayan Forest Thrush as a new species. Throughout the text, the name $Z$. mollissima s.l. refers to the $Z$. mollissima complex as a whole.

\section{Field work}

All taxa were studied in the field (Fig. 1) (except that no certain field observations have been made of the "Yunnan Thrush"). Observations and sound recordings were made at various localities as opportunities arose since the early 1980s. Dedicated studies were carried out in the eastern Himalayas in June 2009 by P.A. and S.D.; in Sichuan Province, China in May and June 2013 by P.A. and Peng Li; in Yunnan Province, China in June 2014 by P.A., C.Z. and Jian Zhao; and in Sichuan Province, China in June 2015 by P.A. and C.Z.

\section{Morphology}

At the start of the morphological analysis it was not known how the different taxa we had noticed in the field differed morphologically, so a large number of mensural and qualitative characters were studied in the attempt to detect differences. We measured and plumage-scored most specimens in key collections of Z. mollissima s.l., as well as samples of $Z$. dixoni. We studied all type specimens of taxa in the complex still recognized: Z. m. whiteheadi (Baker, 1913), 

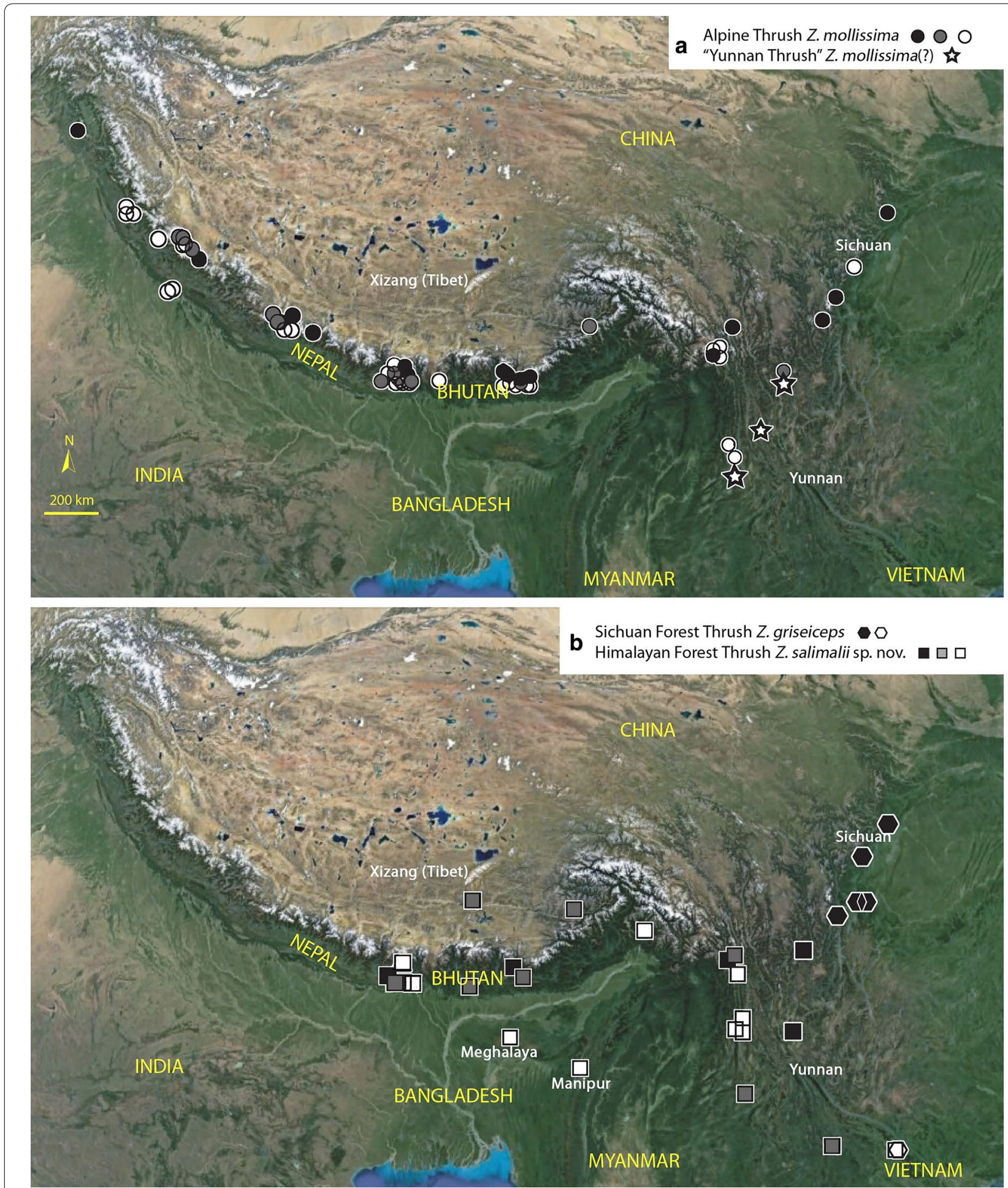

Fig. 1 Distributions of identified records of taxa (as defined herein) of the Z. mollissima complex (Z. dixoni not shown), based on verified specimens, photographs, sound recordings and genetic samples. a Alpine Thrush Z. mollissima sensu stricto (including whiteheadi, synonymized herein) and localities for verified genetic samples of "Yunnan Thrush"Z. mollissima(?). b Himalayan Forest Thrush Z. salimalii sp. nov. and Sichuan Forest Thrush Z. griseiceps. Filled black symbols represent records from June to August, filled grey from April to May and September to October and open symbols from November to March. Multiple site records are not indicated; where multiple records exist from different seasons, site seasonality codes mapped are those during or closest to the breeding season. Labelled provinces and states are those referred to prominently in the text in reference to particular records and/or taxa. The Manipur specimen localities for the Himalayan Forest Thrush could not be traced, so the symbol is arbitrarily located in the center of the western Manipur hill range 
Z. m. simlaensis (Baker, 1924), Z. m. griseiceps (Delacour, 1930), and $Z$. dixoni (Seebohm, 1881), with the exception of the type of $Z$. mollissima (Blyth, 1842), which may be lost. We also studied types of all names that now reside in synonymy: rostrata (Hodgson, 1845), hodgsonii (von Homeyer, 1849) and oreocincloides (Hodgson, 1844) (a nomen nudum). Specimens were studied by P.C.R. at (or were lent by) the following museums: American Museum of Natural History, New York, USA (AMNH); The Natural History Museum, Tring, UK (NHMUK; specimen acronym BMNH); California Academy of Sciences, San Francisco, CA, USA (CALAS); Field Museum of Natural History, Chicago, IL, USA (FMNH); Institute of Zoology, Chinese Academy of Sciences, Beijing, China (IOZ); Kunming Institute of Zoology, Chinese Academy of Sciences, Kunming, China (KIZ); Museum of Comparative Zoology, Harvard University, Cambridge, MA, USA (MCZ); Museum National d'Histoire Naturelle, Paris, France (MNHN); Michigan State University Museum, East Lansing, MI, USA (MSUM); National Museum of Natural History, Smithsonian Institution, Washington, DC, USA (NMNH, specimen acronym USNM); Naturalis Biodiversity Center, Leiden, The Netherlands (NNM, specimen acronym RMNH); Staatliches Naturhistorisches Museum, Braunschweig, Germany (SNMB); University of Michigan Museum of Zoology, Ann Arbor, MI, USA (UMMZ); and Museum fur Naturkunde, Berlin, Germany (ZMB). The specimens in the AMNH, $\mathrm{BMNH}$ and IOZ were also studied by P.A. Specimens at the Zoological Museum of Moscow University (ZMMU) were studied and measured by M.K. A total of 229 measured specimens (including $39 \mathrm{Z}$. dixoni) were included in the analyses, and four live birds were measured in the field by P.A. See Fig. 1 and Additional file 1: Table S1.

Measurements taken and used in the analyses were (in $\mathrm{mm}$, with digital calipers): culmen length from skull; culmen length from gape (taken because this was measured by Blyth for his type of mollissima, which may have been lost); bill width from distal nares; bill depth from distal nares; bill culmen ridge width; length of hook at tip of upper mandible; skull width; rictal bristle length; wing length (flattened and stretched); wingtip length; shortfalls from wingpoint of folded wing of primaries 1-10 (numbered ascendantly); distance from tip of emarginations of primaries 3-5 and notches 2-3; tail length (measured from distal tip of pygostyle, without inserting ruler between feathers to avoid damaging specimens); distances between longest undertail coverts and tail tip and longest uppertail coverts and tail tip; tail graduation (distance between outer and inner rectrices of folded tail); maximum width of central rectrix; maximum and minimum lengths of white on outermost rectrix (not including a thin white stripe edging the rachis in many individuals); tarsus length (to last undivided scute); and hindclaw length (from last scute along top edge of claw). Qualitative scoring was done for 32 plumage and soft-part characters on each of 167 specimens (including $31 \mathrm{Z}$. dixoni) and photos of one captured griseiceps from Jiuding Shan (Additional file 1: Table S1). The characters and brief explanations are listed in Table 1. Univariate summary statistics with Bonferroni-adjusted two-sample $t$ tests, and principal components analyses (PCAs) were done using SYSTAT (SYSTAT Software, Inc.). To achieve maximum inclusion of specimens including holotypes (some of which are missing key characters) and unsexed individuals, one set of two PCAs was run with only three variables in each, while to achieve greater discrimination between groups, another PCA was run with males only and a much larger set of variables.

\section{Song}

We analyzed recordings of songs from $45 \mathrm{Z}$. mollissima s.l. and $10 \mathrm{Z}$. dixoni from throughout their ranges (Fig. 1; Additional file 1: Table S1). For each individual, sonograms were generated in Raven Pro 1.5 (Cornell Laboratory of Ornithology, Ithaca, USA), and ten different strophe types were selected (which in most cases meant ten consecutive strophes). The following variables were measured for each strophe: duration (s), top frequency $(\mathrm{Hz})$, bottom frequency $(\mathrm{Hz})$, mid frequency (top + bottom frequency/2), frequency bandwidth (the range between top and bottom frequency; $\mathrm{Hz}$ ), and peak frequency (the frequency at which maximum power occurs within the selection; $\mathrm{Hz}$ ). In cases where a recording contained fewer than ten song types, all recorded song types were measured. We ran a principal component analysis (PCA) and discriminant function analysis (DFA) in SPSS version 22 (IBM Corp.) using means of all variables as input. Bonferroni-adjusted two-sample $t$ tests were used to test differences between groups in univariate summary statistics using $\mathrm{R}$ 3.2.1 ( $\mathrm{R}$ Core Team 2015). Most recordings analyzed have been uploaded to and are freely available at AVoCet (http://www.avocet.zoology.msu.edu), and a few are also available at xeno-canto (http://www.xeno-canto.org).

\section{DNA}

\section{Sampling and sequencing}

Samples were obtained from 33 Z. mollissima s.l. and four $Z$. dixoni; most of these were toepad samples from museum specimens, including the holotypes of rostrata, $Z$. $m$. simlaensis and Z. m. griseiceps, and specimens from the type series of the latter and of $Z$. m. whiteheadi (Fig. 1; Additional file 1: Table S1). While standard laboratory procedures were used for fresh DNA samples, extractions, amplifications, and sequencing procedures 


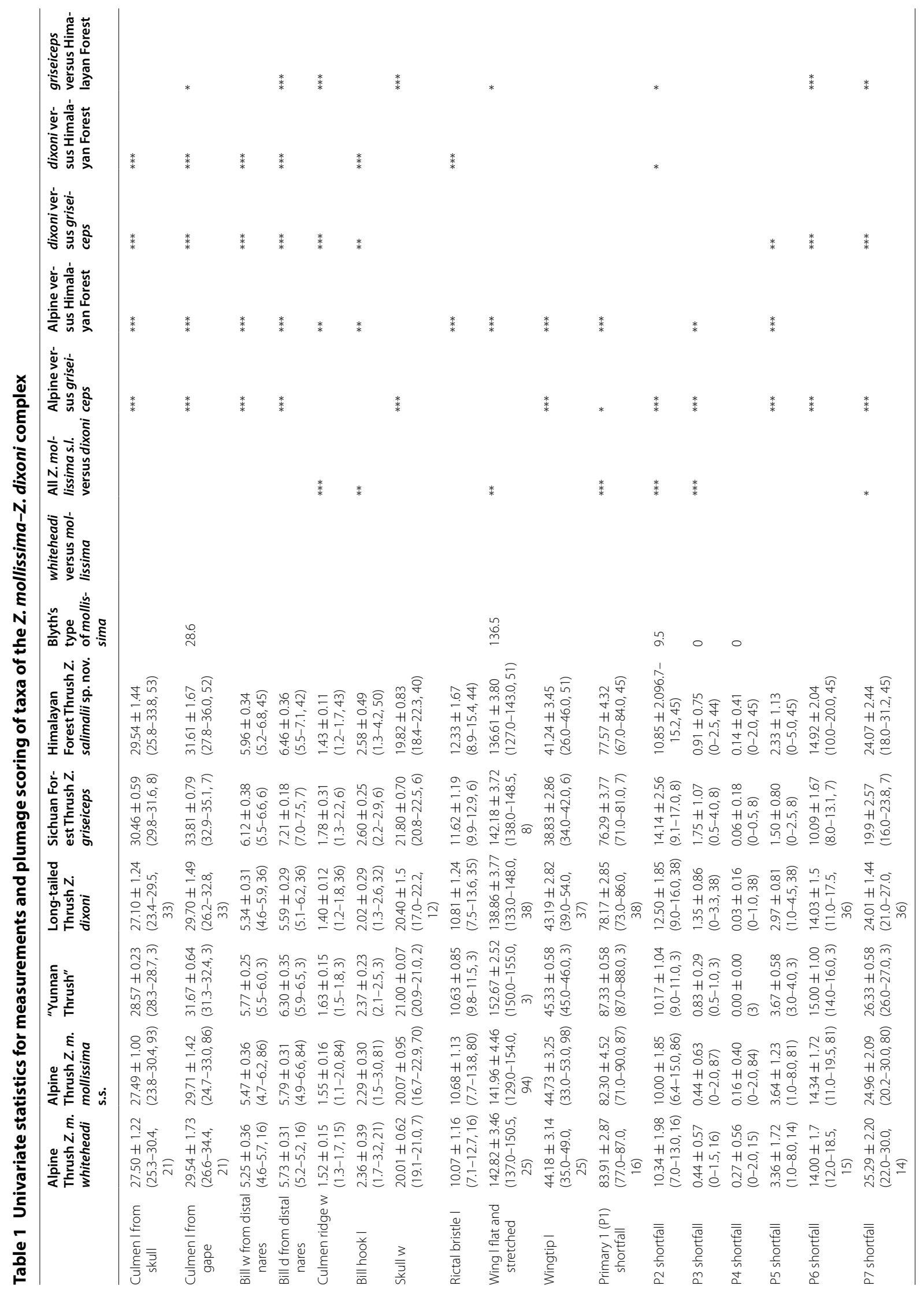




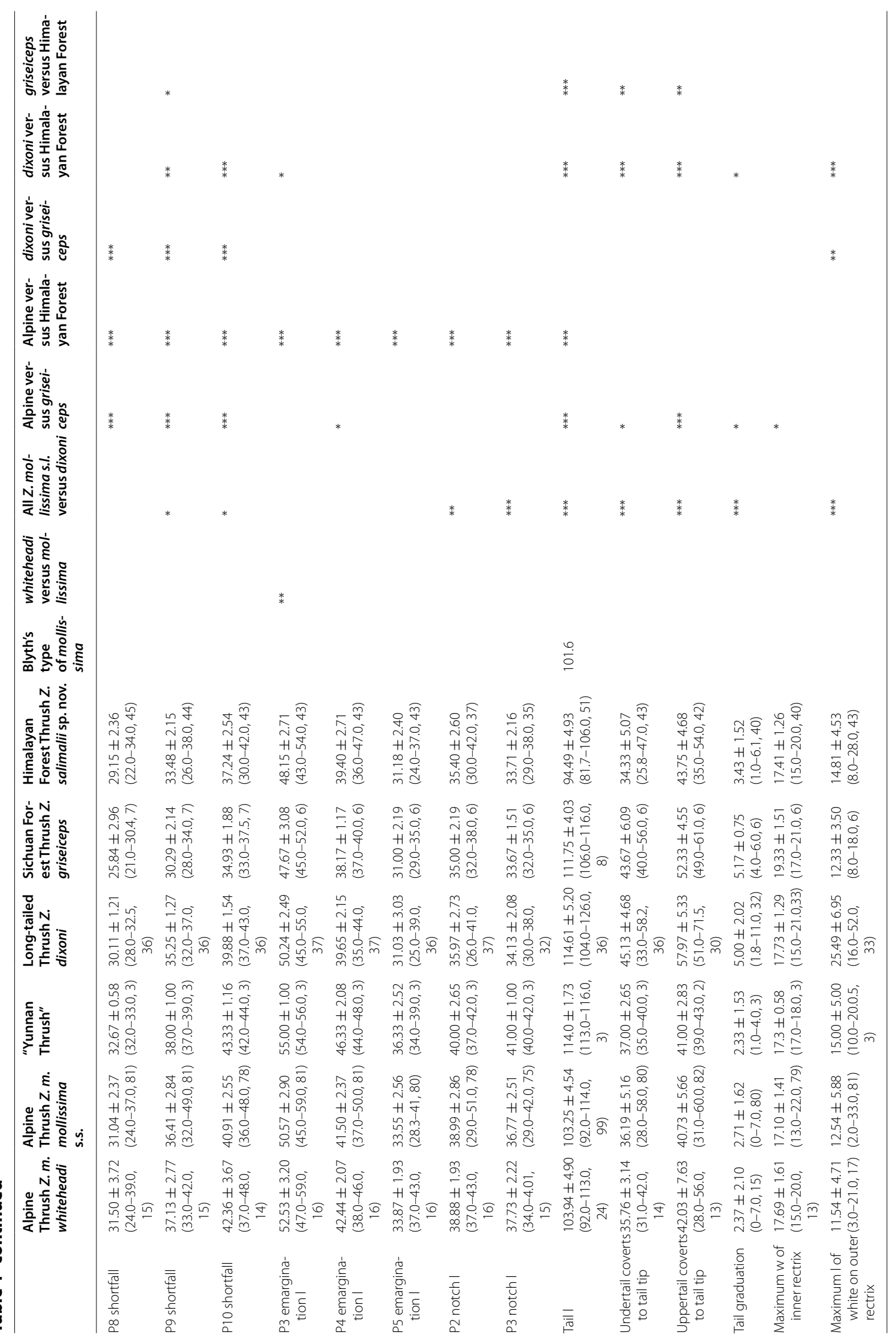




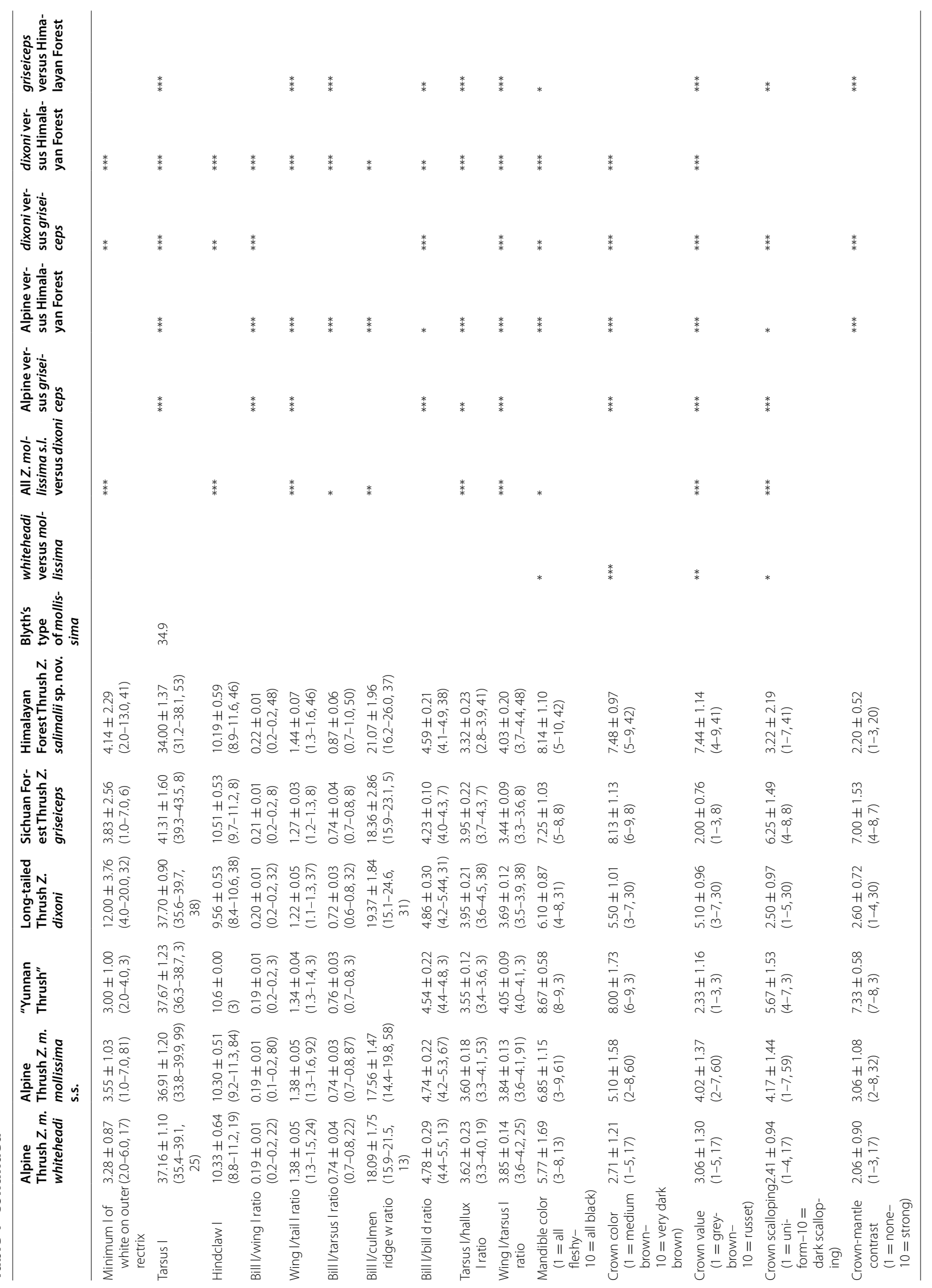




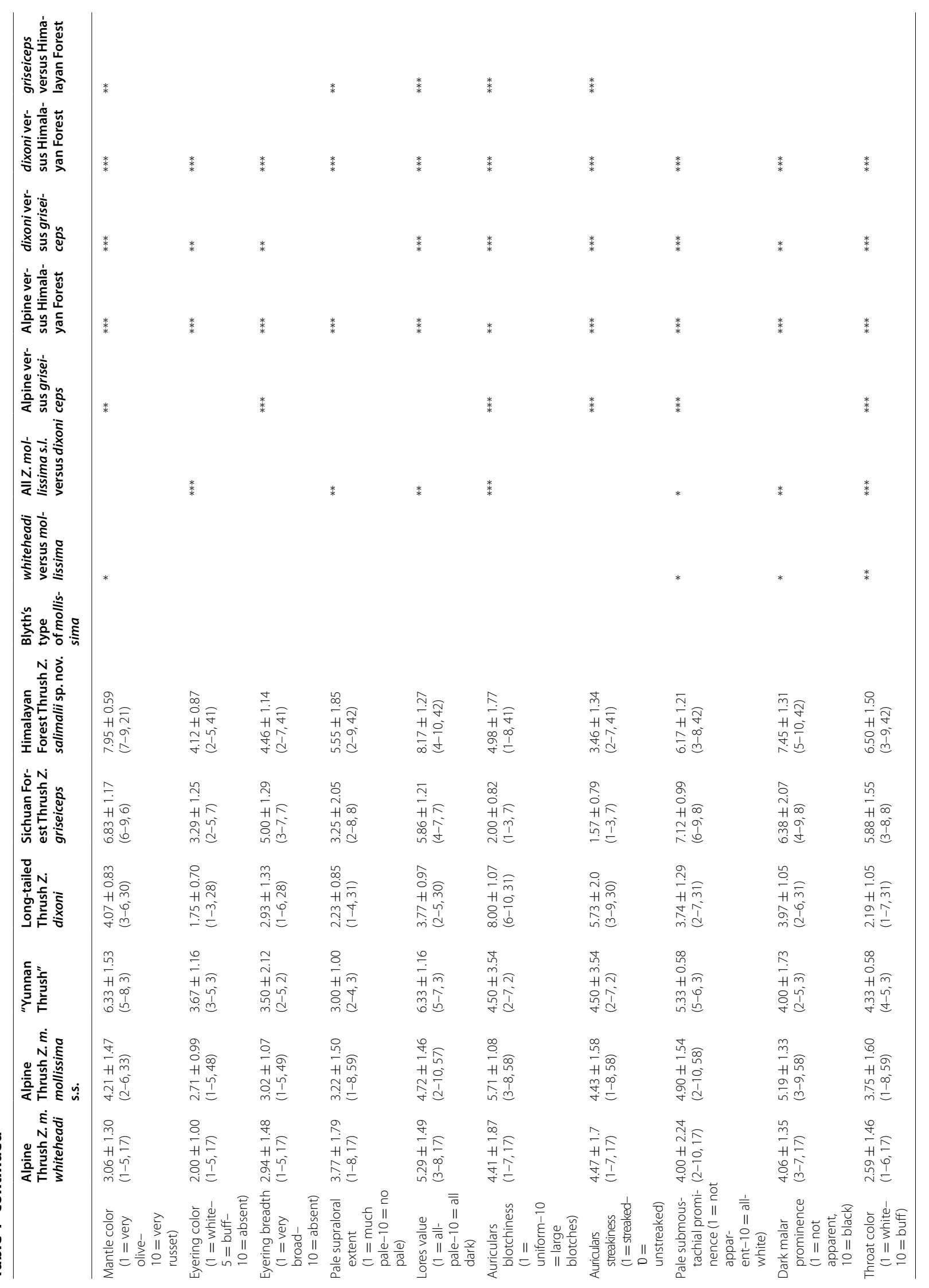




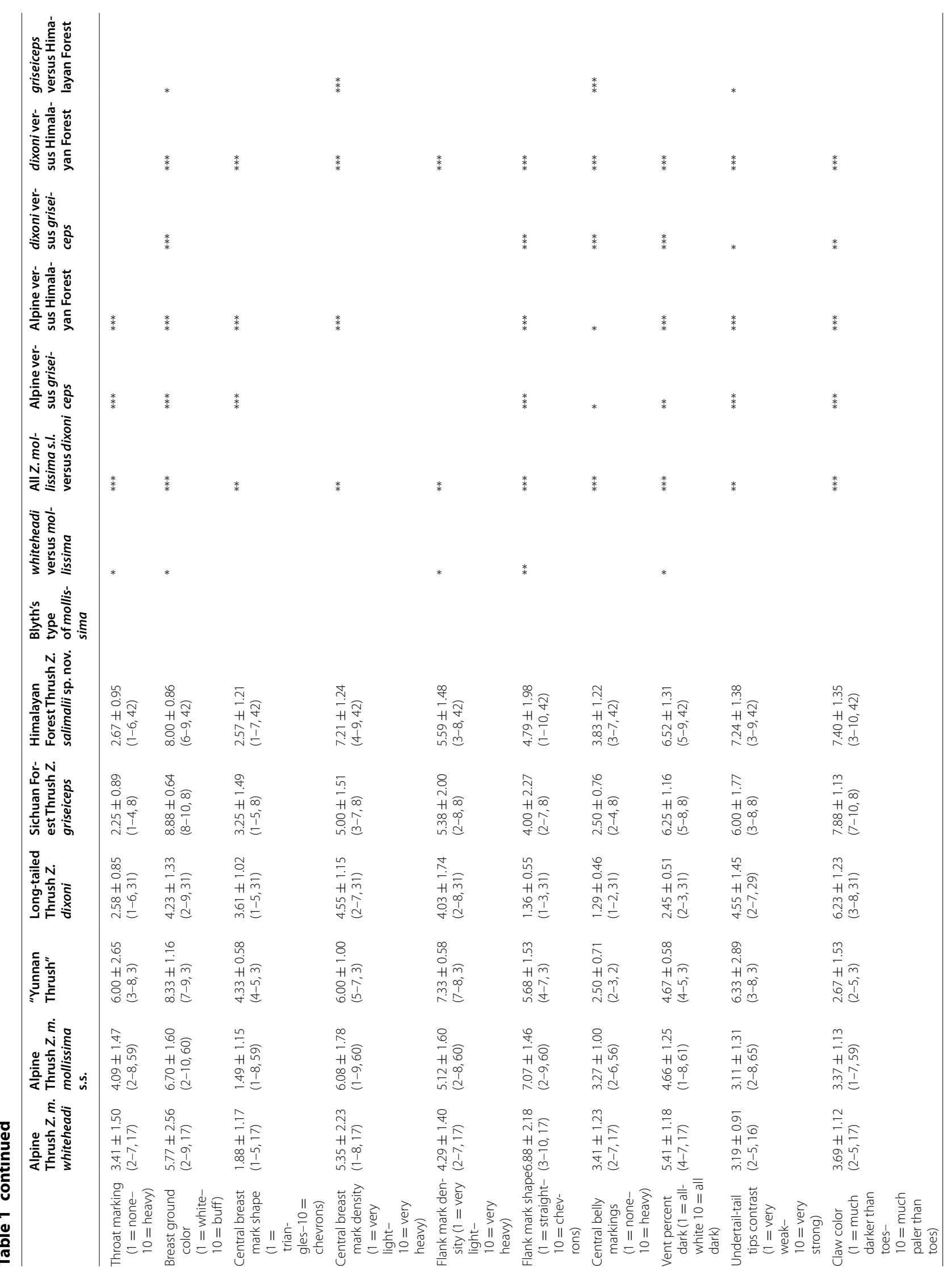




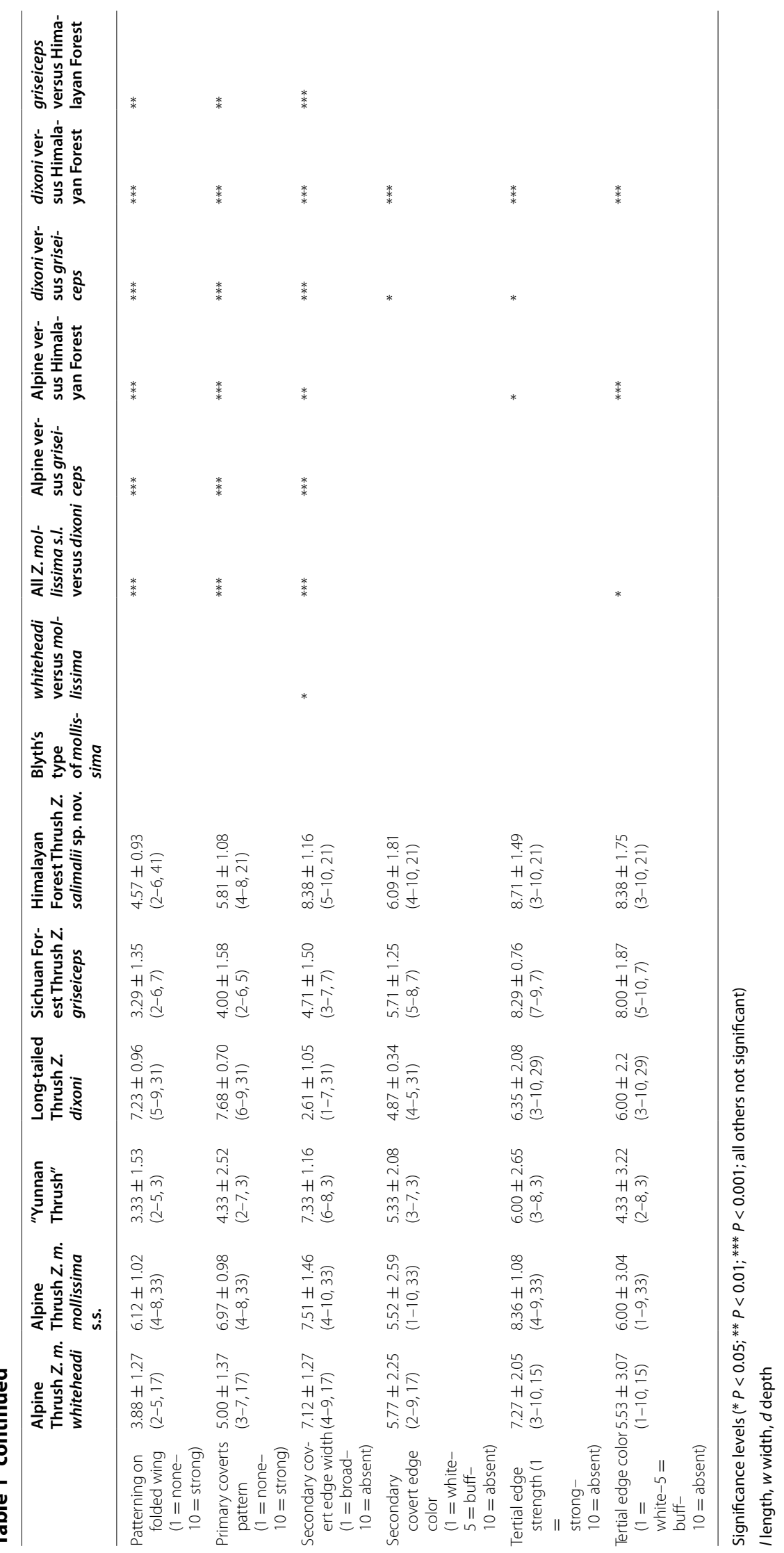


from archaic DNA obtained from study skin samples followed the procedures described in Irestedt et al. (2006). This included e.g. amplifying short (ca. 100-200 bp), partly overlapping fragments using specially designed primers. We sequenced the main part of the mitochondrial cytochrome $b$ gene and part of the flanking tRNA-Thr (combined referred to as cytb), mitochondrial NADH dehydrogenase subunit 2 (ND2) and entire nuclear myoglobin (myo) intron 2 and ornithine decarboxylase (ODC) introns 6-7, although all four loci were only obtained for eight of the $Z$. mollissima s.l. samples, while cyt $b$, myo and ODC were sequenced for $21 \mathrm{Z}$. mollissima s.l. and two Z. dixoni; several of the sequences were incomplete (see Additional file 1: Table S1 and complete alignments in Additional file 2: Data S1). The specimens for which DNA samples were taken were also studied morphologically, and four of them were sound recorded (see Additional file 1: Table S1).

\section{Phylogenetic analysis}

Sequences were aligned using Geneious 7.1 (Biomatters Ltd.); some manual adjustment was carried out for the non-coding sequences. For the nuclear loci, heterozygous sites were coded as ambiguous. Trees were estimated by Bayesian inference (BI) using MrBayes 3.2 (Huelsenbeck and Ronquist 2001; Ronquist and Huelsenbeck 2003) both separately (single-locus analyses) and concatenated, partitioned by locus and, for cyt $b$ and ND2 by codon. Partitioning schemes and models were selected based on the Bayesian information criterion calculated in PartitionFinder 1.1.1 (Lanfear et al. 2012): for all partitions, the HKY model (Hasegawa et al. 1985) was selected, for the cytb partition also an estimated proportion of invariant sites (I; Gu et al. 1995). Rate multipliers were applied to allow different rates for different partitions (Ronquist and Huelsenbeck 2003; Nylander et al. 2004). Ambiguous base pairs and indels were treated as missing data. Default priors in MrBayes were used. Four Metropoliscoupled MCMC chains with incremental heating temperature 0.1 or 0.05 were run for $5 \times 10^{6}$ generations and sampled every 1000 generations. Convergence to the stationary distribution of the single chains was inspected in Tracer 1.6.0 (Rambaut et al. 2014) using a minimum threshold for the effective sample size. The joint likelihood and other parameter values reported large effective sample sizes $(>1000)$. Good mixing of the MCMC and reproducibility was established by multiple runs from independent starting points. Topological convergence was examined by eye and by the average standard deviation of split frequencies $(<0.005)$. The first $25 \%$ of generations were discarded as "burn-in", well after stationarity of chain likelihood values had been established, and the posterior probabilities were calculated from the remaining samples (pooled from the two simultaneous runs). White's Thrush Z. aurea and Sunda Thrush $Z$. andromedae were used as outgroups based on the study by Olsson and Alström (2013).

Cyt $b$ gene trees were also computed with BEAST version 1.8.2 (Drummond et al. 2012). Xml files were generated in the BEAST utility program BEAUti version 1.8.2 and are available as Additional file 3: Data S2. Analyses were run under the HKY model (Hasegawa et al. 1985), with rate variation following a discrete gamma distribution with four rate categories (G; Yang 1994), using (a) a strict molecular clock with the mean rate of $2.1 \% /$ million years (my) (Weir and Schluter 2008) or (b) an uncorrelated lognormal relaxed clock model (Drummond et al. 2006) with the same mean rate, and a birth-death species tree prior. Other priors were used with default values. $50 \times 10^{6}$ generations was run, sampled every 1000 generations. The analysis was run twice. The MCMC output was analysed in Tracer version 1.6 (Rambaut et al. 2014) to evaluate whether valid estimates of the posterior distribution of the parameters had been obtained. The first $25 \%$ of the generations were discarded as "burn-in", well after stationarity of chain likelihood values had been established. Trees were summarized using TreeAnnotator version 1.8.2 (included in BEAST package), choosing "Maximum clade credibility tree" and "Mean heights", and displayed in FigTree version 1.4.0 (Rambaut 2002).

Integrative species tree estimation was performed using "BEAST (Heled and Drummond 2010) in BEAST 1.8.2 for the 24 samples for which at least cyt $b$ and myo were available (for 21 of these, ODC was also available, whereas ND2 was only available for ten of these). The same substitution models as in the other analyses were used. An uncorrelated relaxed clock was applied, with a fixed rate of $2.1 \% /$ my for cyt $b$ and estimated rates for the other loci. A piecewise linear population size model with a constant root was used as a prior for the multispecies coalescent and a birth-death model as prior on divergence times. The $\mathrm{xml}$ file is a available as Additional file 4: Data S3.

Pairwise cyt $b$ distances (1026 bp) were calculated in Mega 6.06 (Tamura et al. 2013). Fregin et al. (2012) recommended using the best-fit model for calculation of genetic distances, but as that model was not available in Mega, only uncorrected $P$ values-which underestimate the actual divergences-were calculated. The other recommendations of Fregin et al. (2012), such as the use of "complete deletion", were followed.

Geographical distributions of taxa defined on the above datasets were mapped for specimens examined, sequenced genetic samples, song recordings, and identifiable photographs archived on Oriental Bird Images (http://www.orientalbirdimages.org). 


\section{Results \\ Morphology}

Our results confirm previously published information that, in plumage, $Z$. dixoni is readily distinguishable from Z. mollissima s.l. by its blackish centres (contrastingly darker than mantle) and broad, clearcut buffy (whitish when worn) tips to median, especially, and greater coverts. The wings of $Z$. mollissima s.l. are more uniformly coloured, with little contrast between darker centres and narrow, indistinct (if any) pale tips to the median and greater coverts. Moreover, the dark marks on the underparts of $Z$. dixoni are straighter than in Z. mollissima s.l., usually less profuse on breast and flanks, and the undertail-coverts are nearly unmarked in $Z$. dixoni. In addition, $Z$. dixoni has a contrasting dark patch on the rear earcoverts, which is less well-marked or lacking in $Z$. mollissima s.l.

The taxa belonging to $Z$. mollissima s.l. differ from each other much less obviously. They can, however, be divided into three main groups based on morphometrics and plumage: Alpine Thrush, Himalayan Forest Thrush, and Sichuan Forest Thrush (Tables 1, 2; Figs. 2, 3, 4, 5, 6, 7, 8). Several Alpine Thrushes (nearly all from outside the breeding season) from Yunnan and Sichuan Provinces are larger than any specimens from the Himalayas (Fig. 2), but no plumage differences have been detected (Fig. 3). The Alpine Thrush has the smallest bill of all taxa (except $Z$. dixoni). With respect to plumage, it is characterized by rather uniformly coloured, fairly cold grey-brown forehead to mantle, with no or at the most very slight contrast between the crown/nape and mantle; typical head pattern with rather pale lower lores (shade varying to some extent with angle of view; usually darkest-looking when viewed slightly from in front, but never showing distinct dark loral stripe), moderately dark subocular/ moustachial area, and extensively pale-mottled auriculars (including upper part), usually with a dark patch at rear; usually narrow whitish or pale buffish tips to the median and greater coverts; rather pale brown edges to the primary coverts and primaries, with blackish tips to the former; usually rather distinct pale pinkish or pale yellowish base to the lower mandible; and pale yellowish or pale orange-tinged legs and toes with dark claws (Figs. 4, 5, 6, $7,8)$. All of these characters differ significantly (usually very highly significantly) in univariate analyses (Table 1), and most contribute strongly to the complete separation of Alpine Thrush from Himalayan Forest Thrush on the plumage/soft part colors PCA (Table 2; Fig. 3): on PC 1, colour, face pattern, throat color, undertail contrast, and wing pattern were most important; while on PC 2, crown color, flank marking shape, claw color, and secondary covert pale tip width were most important in achieving the between-group separation.
The Himalayan Forest Thrush clusters in the PCAs largely separate from other taxa on proportions (Fig. 2), with rather slight overlap with Alpine Thrush. There is less overlap between Himalayan Forest Thrush and Alpine Thrush when only males are included in the PCA (Fig. 2). On univariate statistics (Table 1), the Himalayan Forest Thrush differs significantly from Alpine Thrush on its larger bill (but not larger skull), longer rictal bristles, shorter wing, primary projection, tail and tarsus, among other characters. With respect to plumage (Table 1; Fig. 3), the Himalayan Forest Thrush clusters closest to (but still with near-total group separation on PC 1 from) Sichuan Forest Thrush. However, these two differ distinctly in proportions and in subtle plumage characters that do not contribute much to the PCA (Table 2). Himalayan Forest Thrush differs from the Alpine Thrush by its more rufous-toned upper surface; slightly different face pattern, with darker lower lores and subocular/moustachial area (either forming an isolated dark loral stripe or a continuous dark stripe from the lores to below the eye), usually less extensively pale auriculars (especially on upper part, so that the pale mottling is mainly confined to the lower rear corner), and usually no distinct dark patch on the rear ear-coverts; usually less distinct pale tips to the median and greater coverts and less contrastingly patterned primary coverts and primaries; darker base to the lower mandible (lower mandible usually appearing almost entirely dark); and pale pinkish or purplish-pink legs and toes with pale claws (Figs. 4, 5, 6, 7, 8).

The Sichuan Forest Thrush differs significantly from Himalayan Forest Thrush (Table 1) by its slightly larger bill (on actual measurements, but usually appears proportionately shorter), broader skull, longer wing, and much longer tail and tarsus (with essentially no overlap in the latter two characters). Sichuan Forest Thrush clusters well away from Himalayan Forest Thrush in all mensural PCAs (Table 2; Fig. 2a-c). It differs significantly from Alpine Thrush in its relatively bigger bill and larger head, shorter wing, longer and more graduated tail, and longer tarsus. It further differs from the Alpine Thrush and Himalayan Forest Thrush by its greyer forehead to nape, which contrast clearly with the warmer brown rest of the upperparts; at close range, the crown often shows marginally darker centres and paler fringes, producing a slightly scaly pattern. The face pattern is less contrasting than in both the others, with an indistinct dark loral stripe, rather pale subocular/moustachial area, and fairly uniformly pale-streaked auriculars without any dark patch at rear; and the wings are more uniformly patterned than especially Alpine Thrush, with less contrastingly pale primary coverts and primaries, with less-dark tips to the former, and usually with less distinct pale tips to the median and greater coverts. The lower mandible is 
Table 2 Summary statistics for PCAs presented in Figs. 2 and 3 for the Z. mollissima-Z. dixoni complex

\begin{tabular}{|c|c|c|c|c|c|c|}
\hline \multirow[t]{2}{*}{ Component loadings } & \multicolumn{2}{|c|}{$\begin{array}{l}\text { Reduced external } \\
\text { measurement set } A \text {, } \\
\text { both sexes }\end{array}$} & \multicolumn{2}{|c|}{$\begin{array}{l}\text { Reduced external } \\
\text { measurement set } B \text {, } \\
\text { both sexes }\end{array}$} & \multicolumn{2}{|c|}{$\begin{array}{l}\text { Full external measure- } \\
\text { ment set, males only }\end{array}$} \\
\hline & PC1 & PC 2 & PC1 & PC 2 & PC 1 & PC 2 \\
\hline \multicolumn{7}{|l|}{ External measurements } \\
\hline Culmen I from skull & & & & & -0.49 & 0.04 \\
\hline Bill $w$ from distal nares & -0.03 & 0.10 & & & -0.12 & -0.06 \\
\hline Bill d from distal nares & & & & & -0.17 & 0.05 \\
\hline Culmen ridge w & & & & & 0.03 & 0.06 \\
\hline Bill hook I & & & & & -0.09 & 0.10 \\
\hline Rictal bristle maximum I & & & & & -0.29 & -0.09 \\
\hline Wing I (flat and stretched) & 5.45 & 0.28 & 3.70 & 4.00 & 2.64 & 4.09 \\
\hline Wingtip I & & & & & 0.55 & 1.82 \\
\hline Tail I & & & 7.81 & -1.89 & 8.75 & 1.52 \\
\hline White on outer rectrix, maximum & & & & & 3.30 & -5.55 \\
\hline White on outer rectrix, minimum & & & & & 2.42 & -2.99 \\
\hline Tarsus 1 & 0.87 & -1.74 & 1.33 & 0.01 & 1.28 & 0.40 \\
\hline Hind claw I & & & & & -0.11 & 0.23 \\
\hline Eigenvalues & 30.45 & 3.13 & 76.40 & 19.38 & 102.56 & 62.32 \\
\hline$\%$ total variance explained & 90.22 & 9.28 & 77.83 & 19.74 & 51.78 & 31.45 \\
\hline \multicolumn{7}{|l|}{ Plumage scoring } \\
\hline Lower mandible base color & 0.99 & -0.01 & & & & \\
\hline Crown color & 1.36 & -0.77 & & & & \\
\hline Supraloral & 1.24 & 0.28 & & & & \\
\hline Lores & 1.81 & 0.09 & & & & \\
\hline Auriculars $\%$ pale & 0.39 & 0.08 & & & & \\
\hline Submoustachial prominence & 1.16 & -0.12 & & & & \\
\hline Malar strength & 1.41 & 0.03 & & & & \\
\hline Throat color & 1.82 & 0.01 & & & & \\
\hline Throat markings & -0.27 & 0.81 & & & & \\
\hline Central breast marking shape & 0.7 & -0.88 & & & & \\
\hline Central breast marking density & 0.77 & 0.56 & & & & \\
\hline Flank marking shape & 0.24 & 2.44 & & & & \\
\hline Flank marking density & 0.65 & 0.33 & & & & \\
\hline Undertail-tail tip contrast & 1.60 & -0.86 & & & & \\
\hline Claws darkness & 1.16 & -1.61 & & & & \\
\hline Folded wing pattern strength & -1.05 & -0.47 & & & & \\
\hline Secondary covert edge width & 1.49 & 1.86 & & & & \\
\hline Secondary covert edge color & 0.74 & 0.42 & & & & \\
\hline Upperparts color & 1.74 & -0.41 & & & & \\
\hline Eigenvalues & 26.37 & 15.89 & & & & \\
\hline$\%$ of total variance explained & 36.29 & 21.87 & & & & \\
\hline
\end{tabular}

Loadings deemed especially important in bold italic, those of intermediate importance in italics only

Ilength, $w$ width, $d$ depth

almost wholly dark, and the legs pale pinkish, as in Himalayan Forest Thrush, but the claws vary from pale to dark (Figs. 4, 5, 6, 7, 8).

Measurements and plumage scores show that all examined type specimens except $Z$. m. griseiceps belong to the first group, Alpine Thrush, whereas $Z$. m. griseiceps refers to Sichuan Forest Thrush (see also "Appendix"). Five of the located type specimens (whiteheadi, simlaensis, rostrata, oreocincloides and hodgsonii) cluster on three external measurements within the morphospace of $\mathrm{mol}$ lissima on PCAs (Fig. 2), and not within that of the Himalayan Forest Thrush; there was however slight overlap 

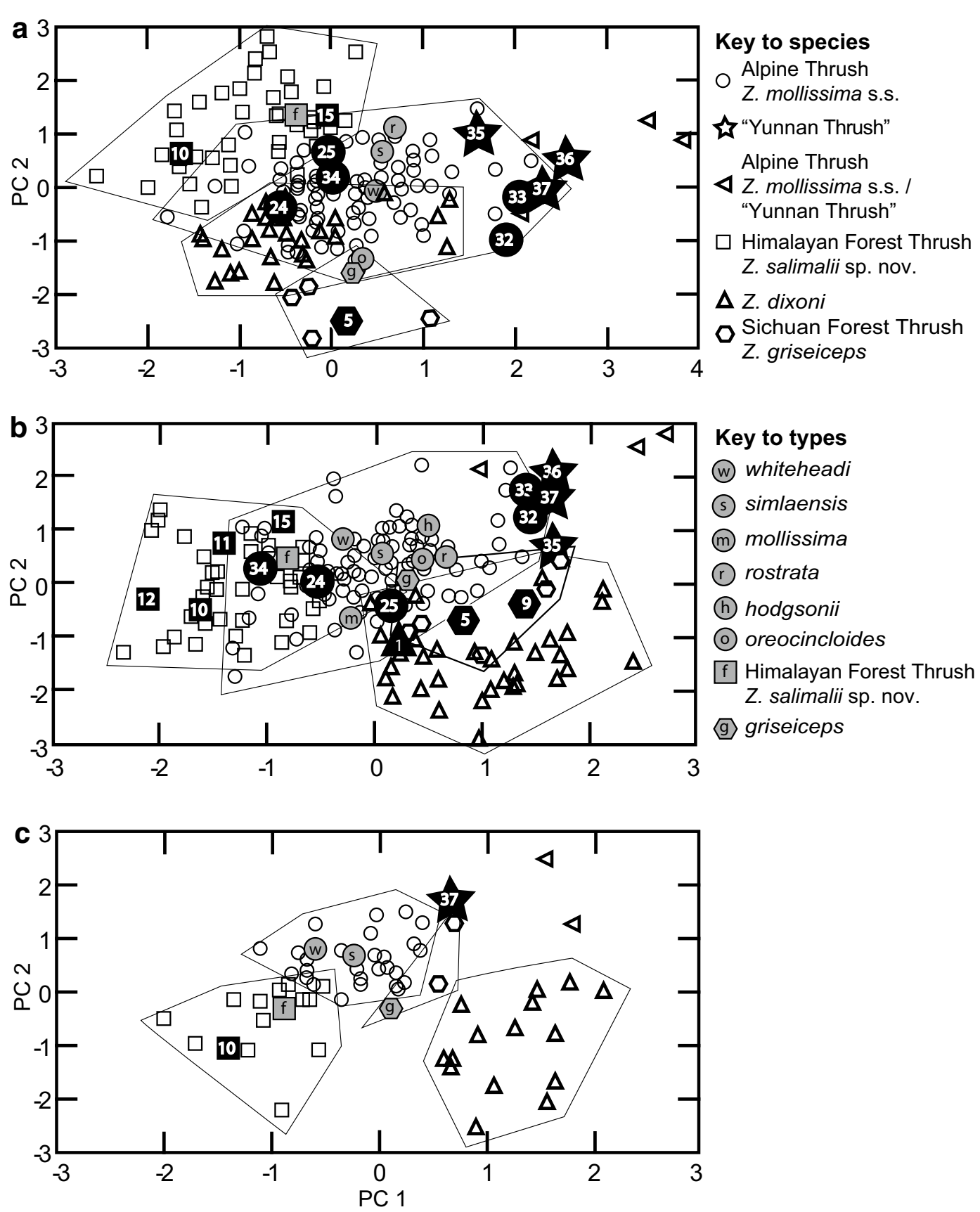

Fig. 2 PCAs of three external measurements (two different sets used to allow inclusion of all holotypes) of skin specimens of taxa of the $Z$. mollissima-Z. dixoni complex, showing position of holotypes (identified by first letter of species name; see key to types; symbols as for their respective taxon but filled grey); and sequenced specimens (numbered as in Additional File 1: Table S1; symbols as for their respective taxon but larger and black with white lettering). a Analysis using bill width, wing, and tarsus. b Analysis using wing, tail, and tarsus, including Blyth's measurements of the female holotype of T. mollissimus Blyth, 1842 (symbol $\mathrm{m}$ ). c PCA of external measurements of skin specimens (males only) of taxa of the Z. mollissima-Z. dixoni complex, showing position of male holotypes. For summary statistics, see Table 2

with dixoni and griseiceps in this analysis. The type specimen of griseiceps clusters with other griseiceps on mensural PCAs (Fig. 2), though with slight overlap with mollissima. The type of mollissima was not available for examination, and appears to have been lost (see "Appendix"), but on Blyth's (1842) measurements it clusters with mollissima, albeit close to some Himalayan Forest Thrushes (Fig. 2). 


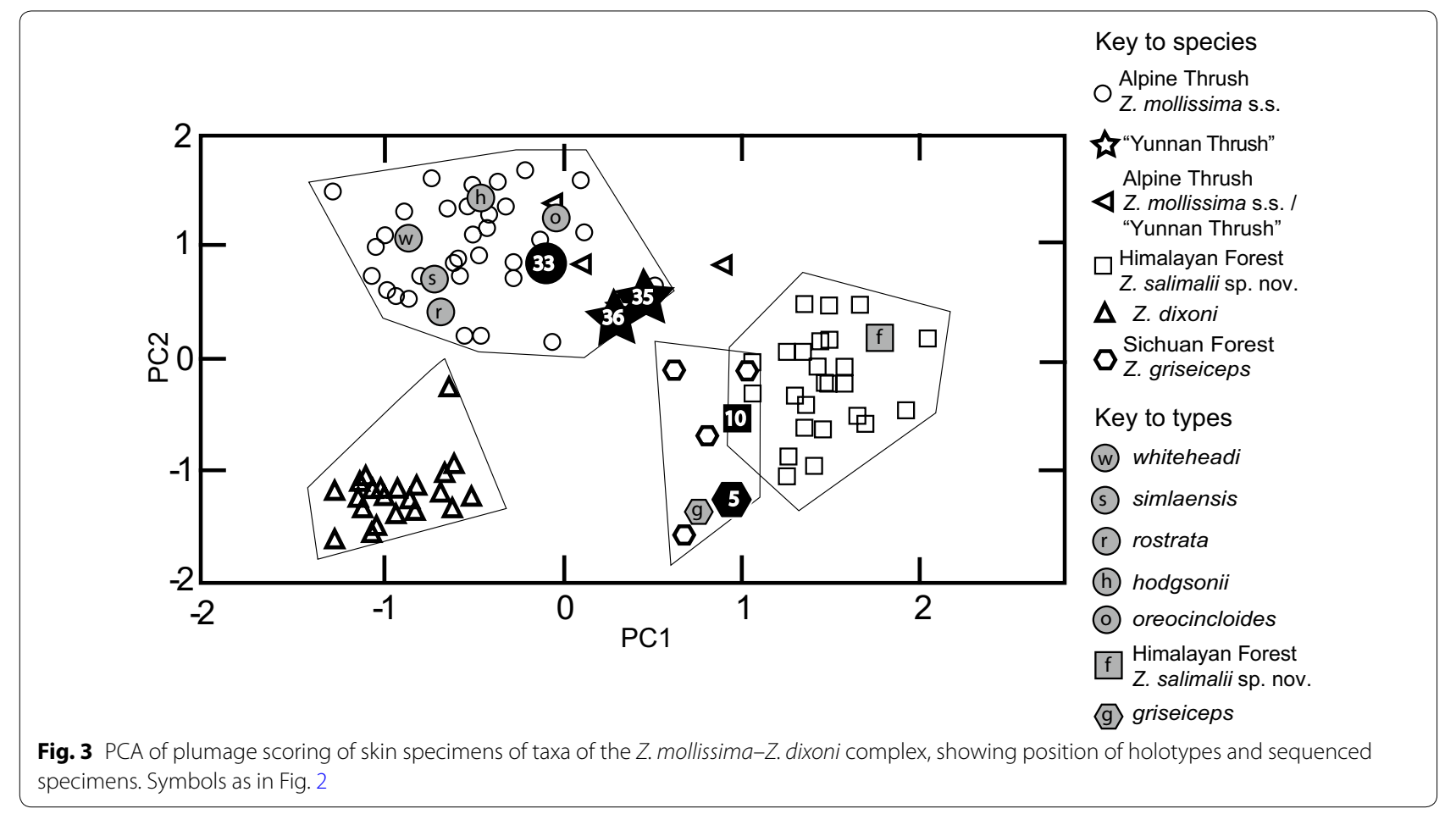

With respect to plumage scores (Fig. 3), the types of whiteheadi, simlaensis, oreocincloides, hodgsonii, and rostrata cluster unambiguously with the Alpine Thrush, not with the Himalayan Forest Thrush or Sichuan Forest Thrush; the missing type of mollissima could not be plumage-scored. The type of griseiceps clusters unambiguously with the Sichuan Forest Thrush with respect to plumage.

The type specimen of whiteheadi (BMNH 1913.10.15.1) is from July and in heavily worn plumage, while the type of simlaensis (BMNH 1886.7.8.2317) is from November and in fresh plumage. Although they appear quite different from each other (whiteheadi being greyishbrown above and the base color below being white, with the rump being especially paler and more olive in some whiteheadi specimens, while simlaensis is much ruddier above and buffier-washed below), these differences are easily explained as seasonal variation, although they are somewhat more marked than is usual. Both on mensural characters and plumage scores, as well as on visual inspection, we found no consistent difference in series between Z. $m$. whiteheadi, Z. m. simlaensis and other Alpine Thrush specimens.

\section{Song}

Audibly and in sonograms, the songs fall into four distinct groups representing Alpine Thrush, Himalayan Forest Thrush, Sichuan Forest Thrush and $Z$. dixoni, with the Alpine Thrush further subdivided into two groups. The song of $Z$. dixoni (Fig. 10; Table 3) is most aberrant. It consists of a slow, irregular ramble of low-pitched, low frequency-band notes, of which some are short, whereas most are various deep-throated, guttural, rolling whistles of different lengths and complexity. The strophes are generally rather poorly defined, and the song may be delivered without distinct strophes.

Song of the Alpine Thrush (Figs. 9, 10; Table 3) consists of short, hurried strophes of highly variable complex notes. The song sounds very unmusical, with a mainly rasping, grating, scratchy, cracked voice and a few squeaky, clearer notes admixed. The tempo is rather even, and the song begins and ends rather abruptly. Sonograms show that a large proportion of the notes are made up of dense series of "noisy" thin elements, and there are few drawn-out clear elements mixed in. The strophes are separated by pauses of varying length, usually several seconds. Each male has a large repertoire, with little or no repetition of entire strophes, although especially the beginnings of the strophes are often repeated in two or three successive strophes. There is no apparent geographical variation in our sample from Uttarakhand, northwest India to Sichuan, China. However, the three "Alpine Thrush type" individuals that we sound recorded in Yunnan Province, China have a slower pace and more deep-throated voice compared to Alpine Thrushes from elsewhere. On sonogram measurements, they differ from 

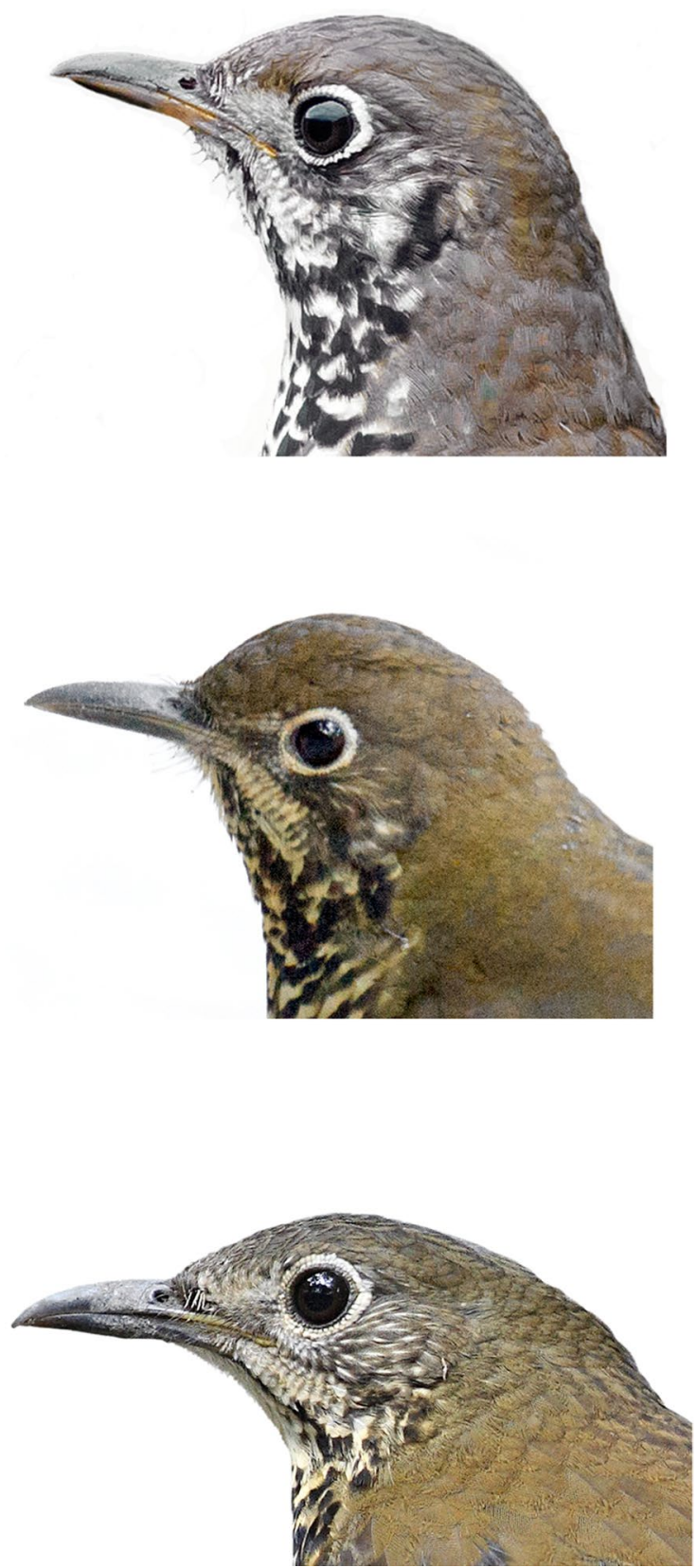

Fig. 4 Heads of Alpine Thrush Z. mollissima sensu stricto (top; Bhutan, late April, Yann Muzika), Himalayan Forest Thrush Z. salimalii, sp. nov. (middle; Baihualing, Yunnan, China, early February, Craig Brelsford) and Sichuan Forest Thrush Z. griseiceps (bottom; Chengdu, Sichuan, China, mid April, Xianwei Yang). Note differences in pattern of lores (least patterned in Alpine, most in Himalayan Forest); subocular/moustachial area (darkest in Himalayan Forest); auriculars (usually extensively pale-mottled throughout, with dark patch at rear in Alpine; variously pale-mottled in Himalayan Forest, mainly in lower rear corner, with indistinct or no dark patch at rear; usually rather uniformly, thinly palestreaked in Sichuan Forest); colour contrast (Sichuan Forest) or lack of colour contrast (two others) between top of head and mantle; and colour of base of lower mandible (usually pale in Alpine, dark in others). Bill proportionately largest in Himalayan Forest and smallest in Alpine Thrush, but this Himalayan Forest has unusually small bill
Himalayan and Sichuan birds in having on average more drawn-out strophes with lower pitch and narrower frequency band (Fig. 10; Table 3; see also PCA and DFA).

The song of the Himalayan Forest Thrush (Figs. 10, 11; Table 3) sounds much more musical and "thrush-like" than that of Alpine Thrush. It is built up of a mix of rich, drawn-out clear notes and shorter, thinner ones, with hardly any harsh scratchy notes. The speed is slower, the variation in pitch among the notes is more pronounced than in Alpine Thrush, and the strophes often end with thinner notes than at the beginning, making the song seem to trail off at the end. No differences are apparent between birds from the Himalayas and Yunnan Province, China. Individual variation as described above for Alpine Thrush.

The song of the Sichuan Forest Thrush (Fig. 12; Table 3) is most similar to that of the Himalayan Forest Thrush, but the former has an even deeper, richer voice, with even more drawn-out, musical, fluty notes, slower overall speed, and on average more halting endings to the strophes. The strophes given by Sichuan Forest Thrush average longer, with narrower frequency band, lower mid-frequency and lower peak frequency than in the Himalayan Forest Thrush. Individual variation is as in the previous taxa.

In the PCA of song variables (Fig. 13), the Alpine Thrush, Himalayan Forest Thrush, Sichuan Forest Thrush and $Z$. dixoni formed separate clusters, with the Alpine Thrush subdivided into two clusters (Himalayan + Sichuan birds and Alpine Thrush/"Yunnan Thrush" from Yunnan, respectively). PC1 and PC2, which had eigenvalues $>1$, explained $82.5 \%$ of the variance. PC1 was mainly determined by the duration of the strophes, top frequency and frequency range, whereas PC2 was mainly influenced by bottom frequency and peak frequency (Additional file 5: Table S2). Zoothera dixoni was separated from the others by $\mathrm{PC} 1$, and from Alpine and Sichuan Forest Thrushes by PC2, whereas Alpine, Himalayan Forest and Sichuan Forest Thrushes were separated by PC2; the eight Alpine Thrushes from the Himalayas and Sichuan were separated from the three Alpine Thrush/"Yunnan Thrush" from Yunnan by PC1.

In the DFA of all taxa (Additional file 5: Table S2), with the Alpine Thrush types from Yunnan included as a separate group (Alpine Thrush/“Yunnan Thrush"), frequency band width failed the tolerance test, and was therefore excluded from the analysis. Functions 1 and 2 explained $96.2 \%$ of the variance, and Wilk's Lambda for functions 1-4 was highly significant $\left(0.014\right.$; Chi square ${ }_{16} 209.633$, $P<0.0001)$. The variables most important for discrimination were bottom frequency (both functions), strophe length, peak frequency (Function 1) and top frequency (Function 2) (Additional file 5: Table S2). The DFA 


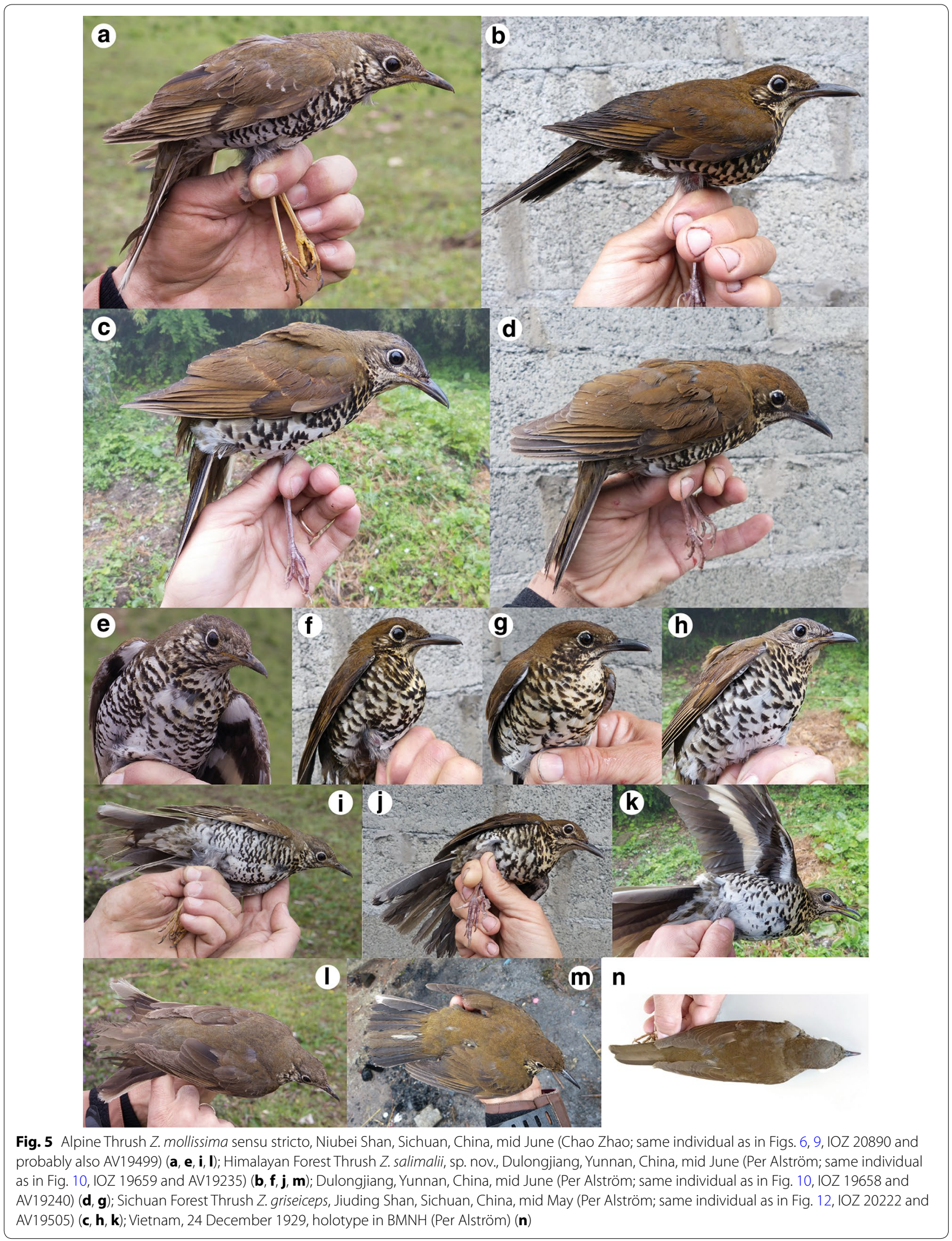




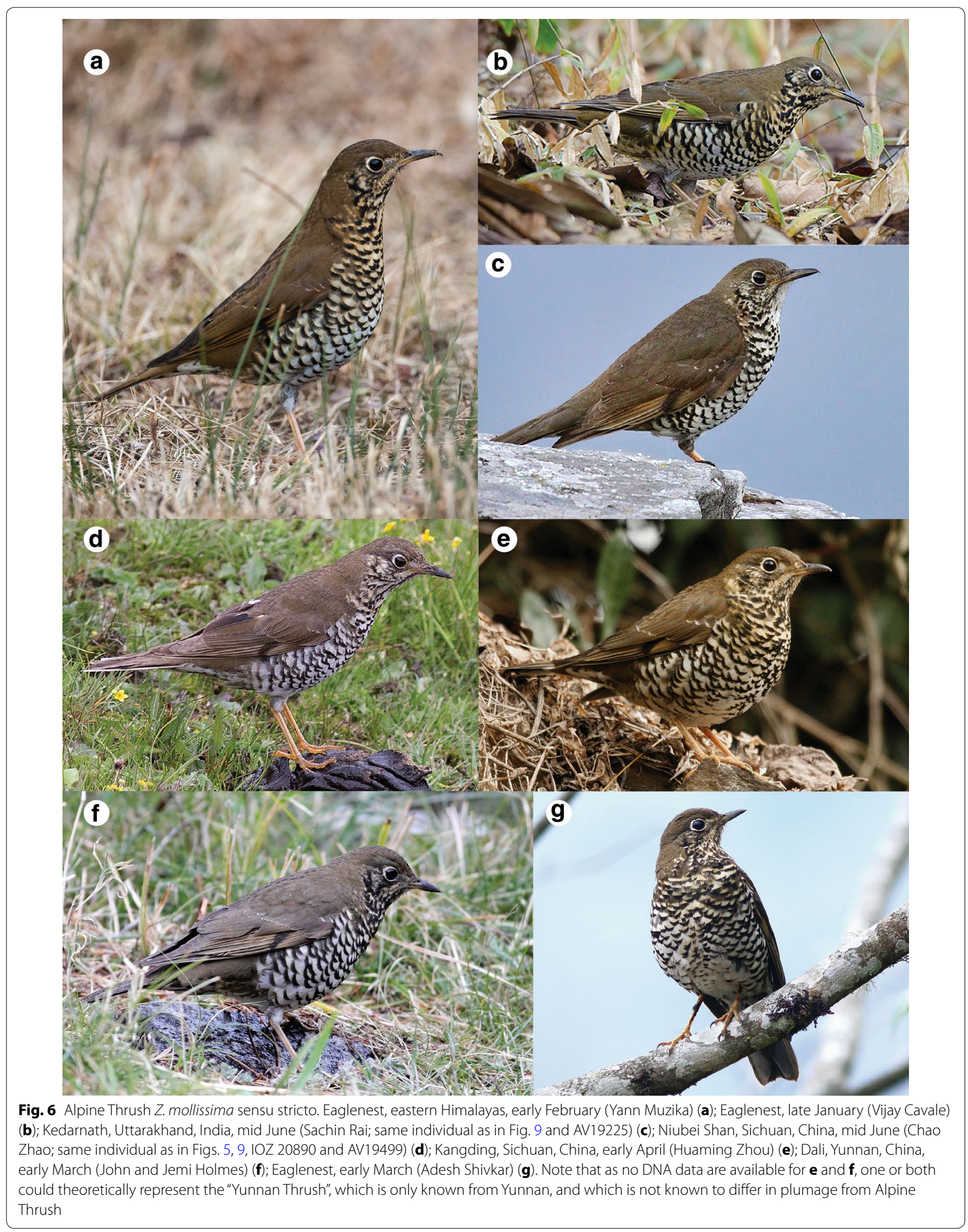






Fig. 7 Himalayan Forest Thrush Z. salimalii, sp. nov., Darjeeling District, West Bengal, India (Subrato Sanyal) (a); Baihualing, Yunnan, China, early February (Craig Brelsford; same individual as in Fig. 4, but other side of head; the tail has apparently been accidentally lost and is growing) (b); Darjeeling District, West Bengal, India (Subrato Sanyal; different individual from a) (c); Dulongjiang, Yunnan, mid June (Craig Brelsford; same individual) (d-f)

resulted in $94.5 \%$ correct classification of the five groups; one Alpine Thrush from the Himalayan + Sichuan group and one Himalayan Forest Thrush were predicted to belong in the Alpine Thrush/"Yunnan Thrush" group; and one Sichuan Forest Thrush was predicted to belong with $Z$. dixoni. After cross validation, $90.9 \%$ were correctly classified; in addition to the misclassified ones above, there was also one Himalayan Forest Thrush predicted 


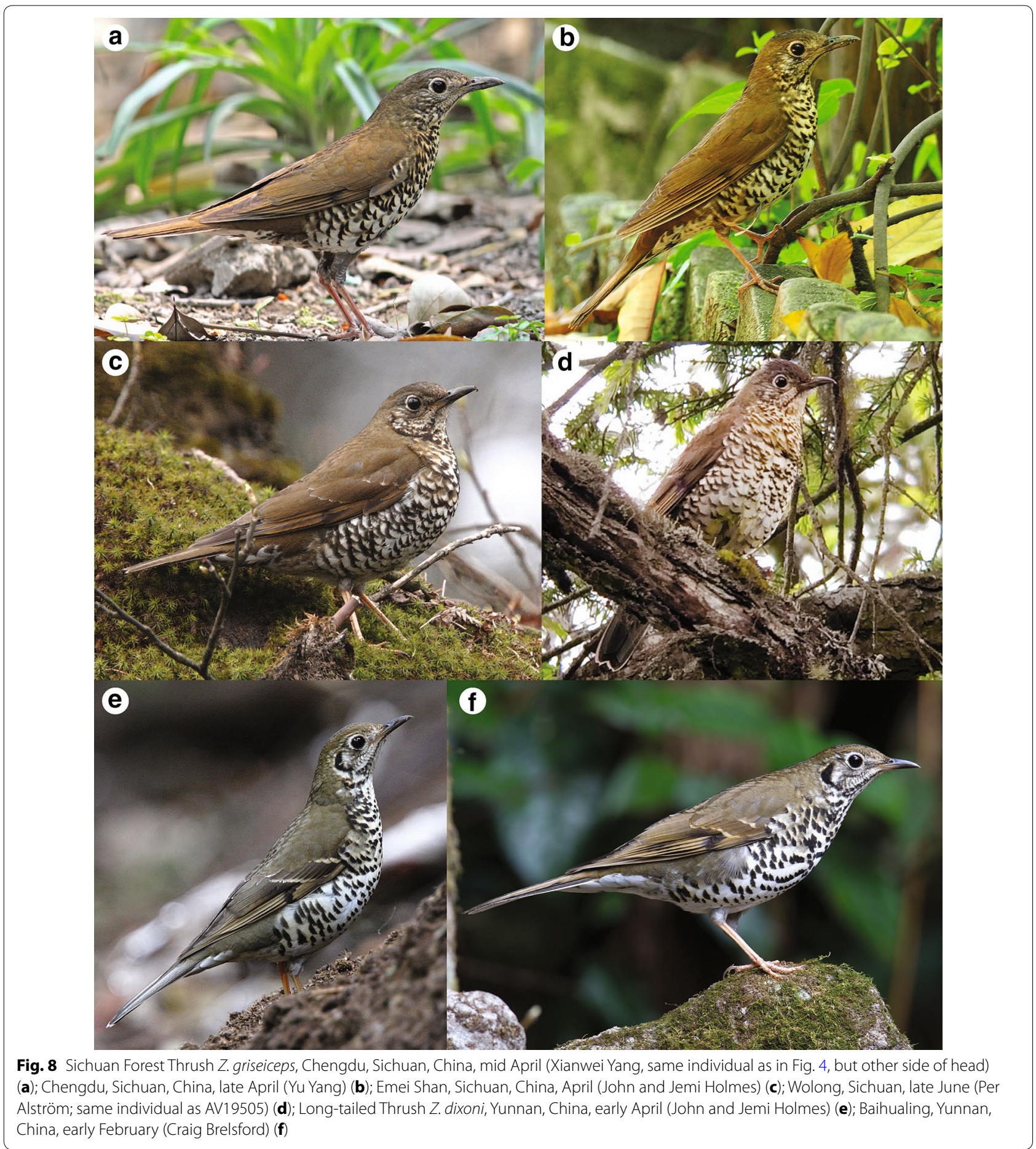

to belong in the Himalayan + Sichuan Alpine Thrush group. All sound recordings of Himalayan Forest Thrush and Sichuan Forest Thrush were easily distinguishable from all Alpine Thrushes and $Z$. dixoni both by ear and on sonograms.

\section{DNA}

The cytb tree including all samples (Fig. 14) recovered five deeply diverged primary clades representing Alpine Thrush from the Himalayas and Sichuan (clade A); birds collected in Yunnan in the non-breeding season with 
Table 3 Univariate measurements for song characteristics

\begin{tabular}{|c|c|c|c|c|c|c|c|c|c|}
\hline & N. inds. & N. str. & & Duration (s) & Top freq. $(\mathrm{Hz})$ & $\begin{array}{l}\text { Bottom freq. } \\
(\mathrm{Hz})\end{array}$ & $\begin{array}{l}\text { Freq. band- } \\
\text { width }(\mathrm{Hz})\end{array}$ & Peak freq. (Hz) & Mean freq. $(\mathrm{Hz})$ \\
\hline \multirow[t]{3}{*}{ Alpine Thrush } & 8 & 79 & Mean & 2.57 & 8220.1 & 1678.9 & 6541.2 & 4177.2 & 4754.9 \\
\hline & & & SD & 0.48 & 555.3 & 227.3 & 663.6 & 691.8 & 420.2 \\
\hline & & & Range & $1.85-4.28$ & 6505.7-9192.1 & 1176.7-2157.6 & $4691.6-7762.6$ & $2812.5-5437.5$ & $3699.1-6236.7$ \\
\hline \multirow{3}{*}{$\begin{array}{l}\text { "Yunnan Thrush"/ } \\
\text { Alpine Thrush }\end{array}$} & 3 & 26 & Mean & 3.36 & 6915.9 & 1946.5 & 4969.4 & 3396.6 & 4611.0 \\
\hline & & & SD & 0.39 & 537.2 & 179.5 & 548.9 & 227.0 & 652.3 \\
\hline & & & Range & $2.62-4.40$ & $5581.1-7811.5$ & $1641.2-2256.9$ & $3573.1-5802.6$ & $3000-3750$ & 3038.4-6138.3 \\
\hline \multirow{3}{*}{$\begin{array}{l}\text { Sichuan Forest } \\
\text { Thrush }\end{array}$} & 17 & 168 & Mean & 4.38 & 7412.7 & 1141.2 & 6271.5 & 2517.3 & 4276.9 \\
\hline & & & SD & 1.19 & 1305.7 & 158.5 & 1293.1 & 457.0 & 668.6 \\
\hline & & & Range & $1.98-8.61$ & $3231.4-10,011.0$ & $676.2-1471.2$ & $2157.5-8643.1$ & $1894.9-5812.5$ & $2152.7-5689.5$ \\
\hline \multirow{3}{*}{$\begin{array}{l}\text { Himalayan Forest } \\
\text { Thrush }\end{array}$} & 17 & 161 & Mean & 2.74 & 8023.7 & 1467.4 & 6556.4 & 3138.8 & 4745.5 \\
\hline & & & SD & 0.51 & 952.9 & 182.1 & 991.7 & 572.0 & 474.0 \\
\hline & & & Range & $1.24-5.58$ & $4659.6-11,087.4$ & $719.6-1914.0$ & 2792.8-9701.5 & $2250.0-5625.0$ & $3038.4-6236.7$ \\
\hline \multirow[t]{3}{*}{ Z. dixoni } & 10 & 80 & Mean & 5.79 & 3949.9 & 1787.2 & 2162.7 & 2747.1 & 2868.6 \\
\hline & & & SD & 4.53 & 331.7 & 193.5 & 402.7 & 182.5 & 182.2 \\
\hline & & & Range & $0.78-19.73$ & $3480.3-5349.7$ & 1073.9-2048.4 & 1471.7-3520.1 & $2250.0-3100.8$ & $2565.5-3589.7$ \\
\hline $\begin{array}{l}\text { Alpine versus } \\
\text { "Yunnan"/ } \\
\text { Alpine }\end{array}$ & & & & $* * *$ & $* * *$ & $* * *$ & $* * *$ & $* * *$ & \\
\hline $\begin{array}{l}\text { Alpine versus } \\
\text { Himalayan } \\
\text { Forest }\end{array}$ & & & & & & $* * *$ & & $* * *$ & \\
\hline $\begin{array}{l}\text { Alpine versus } \\
\text { Sichuan Forest }\end{array}$ & & & & $* * *$ & $* * *$ & $* * *$ & & $* * *$ & $* * *$ \\
\hline $\begin{array}{l}\text { Alpine versus } Z \text {. } \\
\text { dixoni }\end{array}$ & & & & $* * *$ & $* * *$ & & $* * *$ & $* * *$ & $* * *$ \\
\hline $\begin{array}{l}\text { "Yunnan"/Alpine } \\
\text { versus Himala- } \\
\text { yan Forest }\end{array}$ & & & & $* * *$ & $* * *$ & $* * *$ & $* * *$ & $* *$ & \\
\hline $\begin{array}{l}\text { "Yunnan"/Alpine } \\
\text { versus Sichuan } \\
\text { Forest }\end{array}$ & & & & $* * *$ & & $* * *$ & $* * *$ & $* * *$ & \\
\hline $\begin{array}{l}\text { "Yunnan"/Alpine } \\
\text { versus Z. dixoni }\end{array}$ & & & & $* * *$ & $* * *$ & * & $* * *$ & $* * *$ & $* * *$ \\
\hline $\begin{array}{l}\text { Himalayan Forest } \\
\text { versus Sichuan } \\
\text { Forest }\end{array}$ & & & & $* * *$ & $* * *$ & $* * *$ & & $* * *$ & $* * *$ \\
\hline $\begin{array}{l}\text { Himalayan Forest } \\
\text { versus Z. dixoni }\end{array}$ & & & & $* * *$ & $* * *$ & $* * *$ & $* * *$ & $* * *$ & $* * *$ \\
\hline $\begin{array}{l}\text { Sichuan Forest } \\
\text { versus Z. dixoni }\end{array}$ & & & & & $* * *$ & $* * *$ & $* * *$ & $* * *$ & $* * *$ \\
\hline
\end{tabular}

"Yunnan"/Alpine-birds sound recorded in Yunnan Province, which is hypothesised to be "Yunnan Thrush", but for which no DNA samples exist (cf. Figs. 10, 13), N. inds.- number of individuals used in the analysis, N. str.- number of strophes used in the analysis

Mean freq. $-0.5 \times$ (HighFreq + LowFreq). Two-sample $t$ test with Bonferroni correction

Significance levels ${ }^{*} P<0.05$; ${ }^{*} P<0.01 ;{ }^{* *} P<0.001$; all others not significant

morphology similar to birds in the first clade ("Yunnan Thrush", clade B); Himalayan Forest Thrush (clade C); Sichuan Forest Thrush (clade D); and Z. dixoni (clade E). The two former were sisters (clade AB) as were the two other Z. mollissima s.l. taxa (clade CD), while Z. dixoni was sister to $Z$. aurea $+Z$. andromedae (clade F). All these primary clades were strongly supported (PP 1.00), though the relationships among clades $A B, C D, E$ and $F$ were unsupported. The holotypes of rostrata and Z. m. simlaensis, and the two $Z$. $m$. whiteheadi from the type series were in the Alpine Thrush clade (A), and the holotype of Z. $m$. griseiceps was in the Sichuan Forest Thrush clade (D).

The *BEAST phylogeny inferred the same topology as the BEAST cyt $b$ tree, with poor support for the deepest 


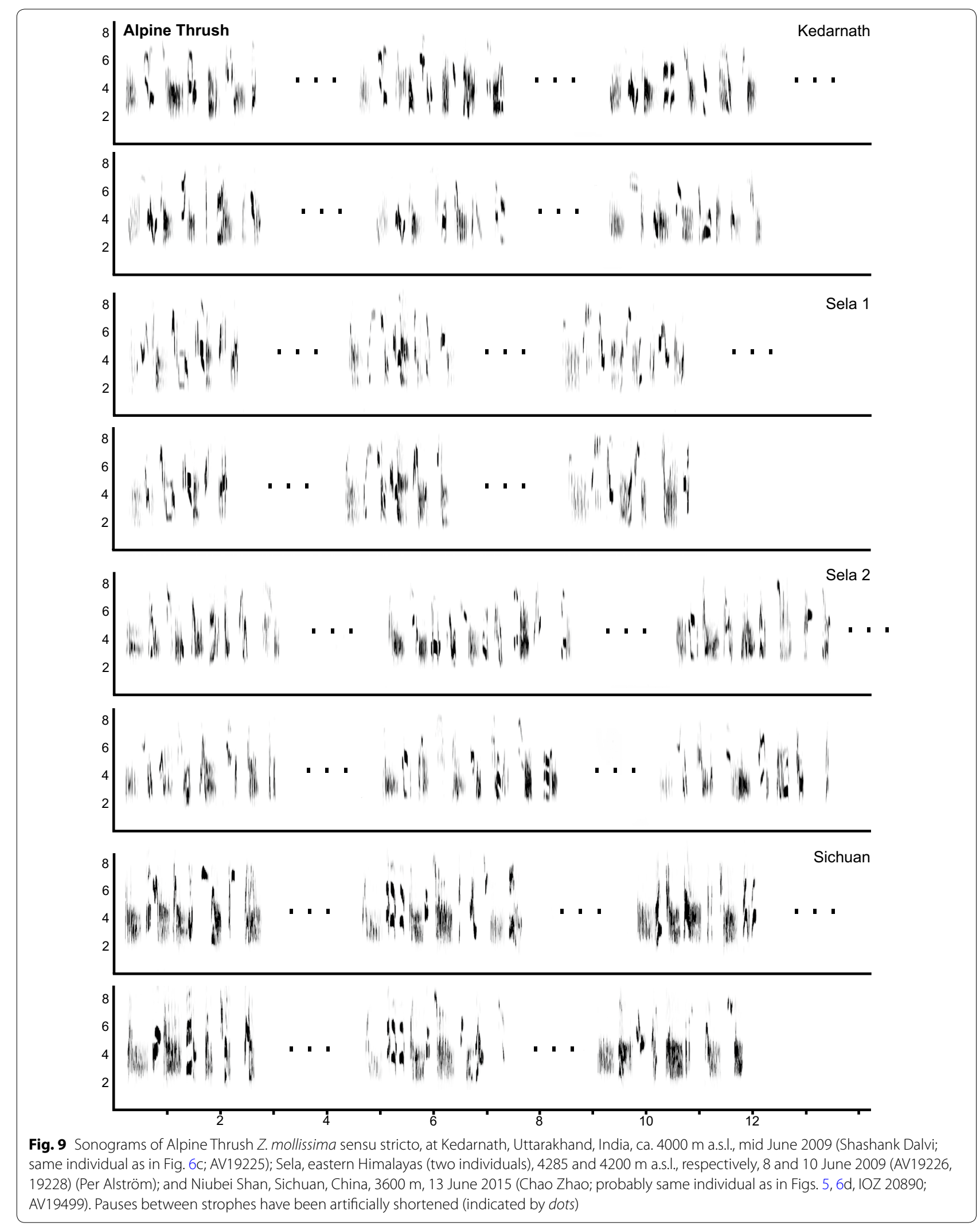




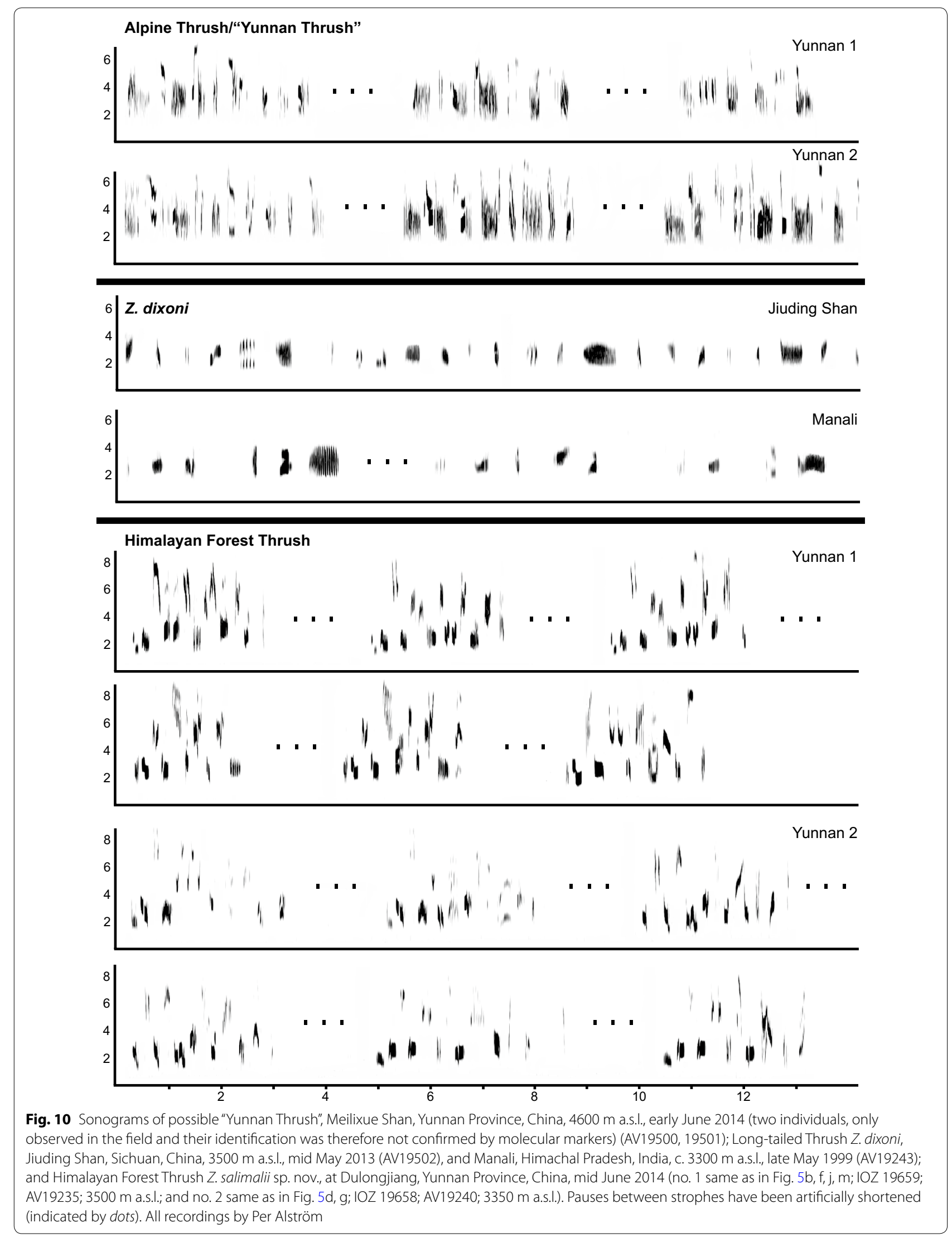




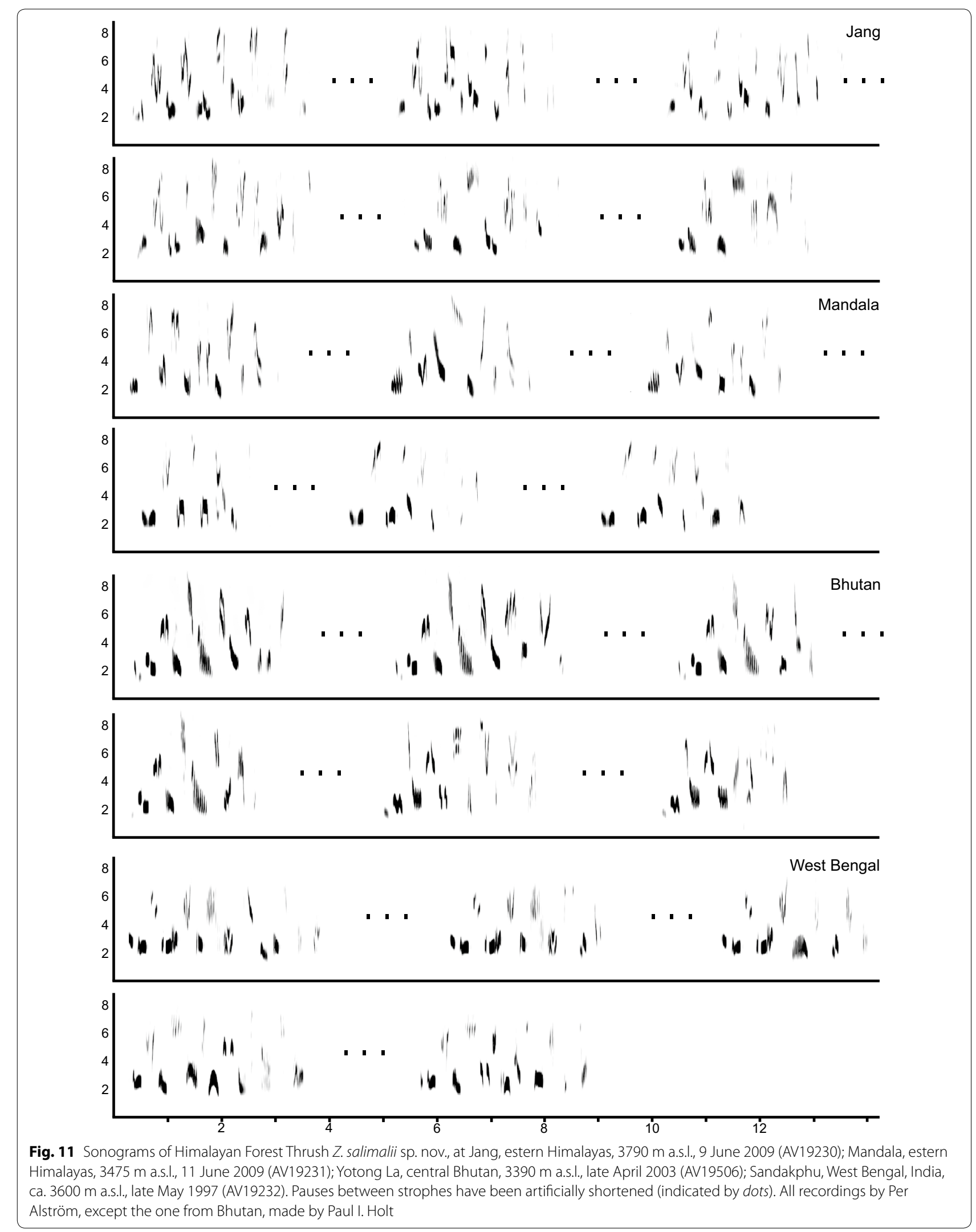



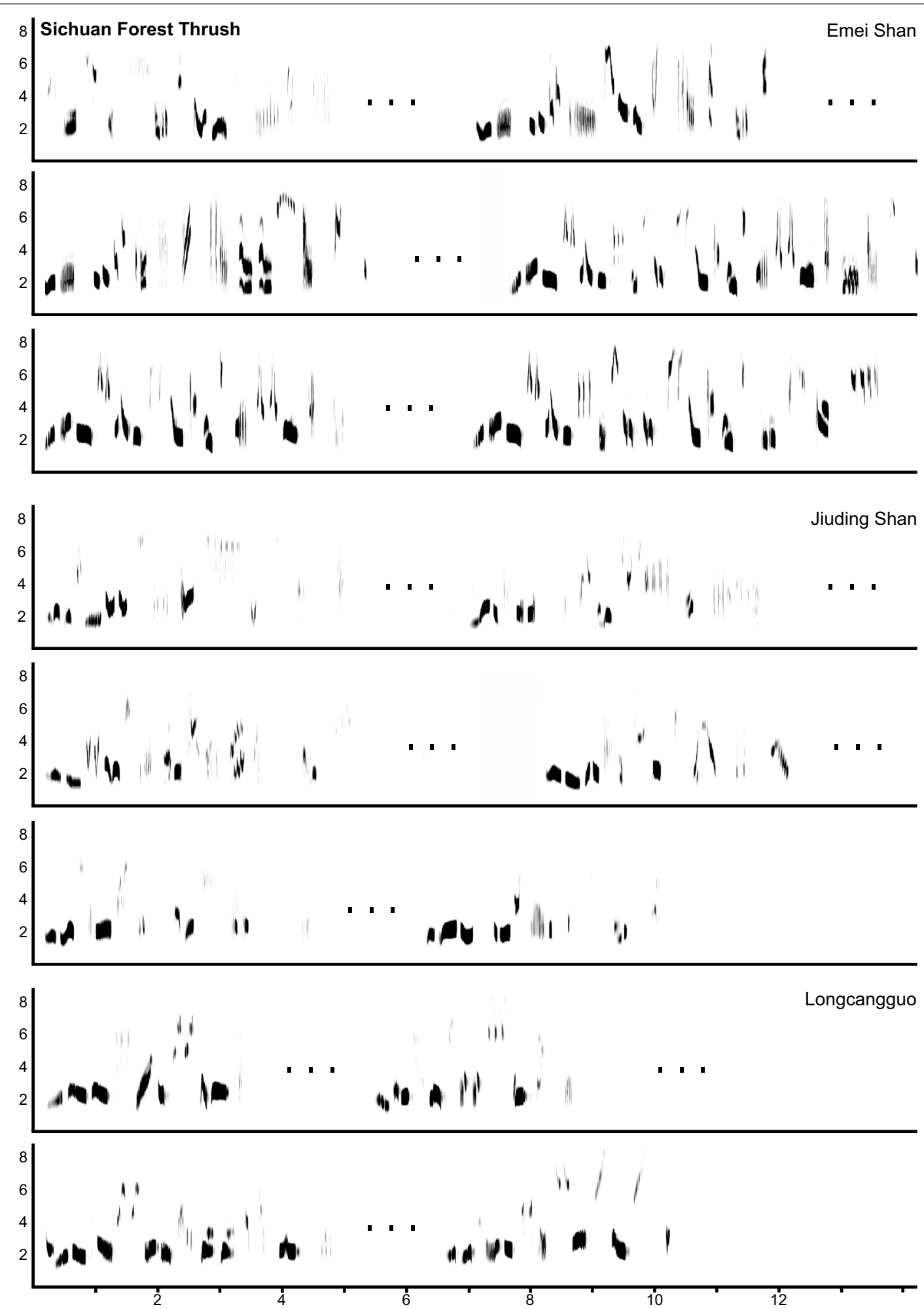

Fig. 12 Sonograms of Sichuan Forest Thrush Z. griseiceps, in Sichuan, China, at Emei Shan, mid May 1989 (AV19503); Jiuding Shan, mid May 2013 (AV19505); and Longcangguo, late May 2013 (AV19504). Pauses between strophes have been artificially shortened (indicated by dots). All recordings by Per Alström 


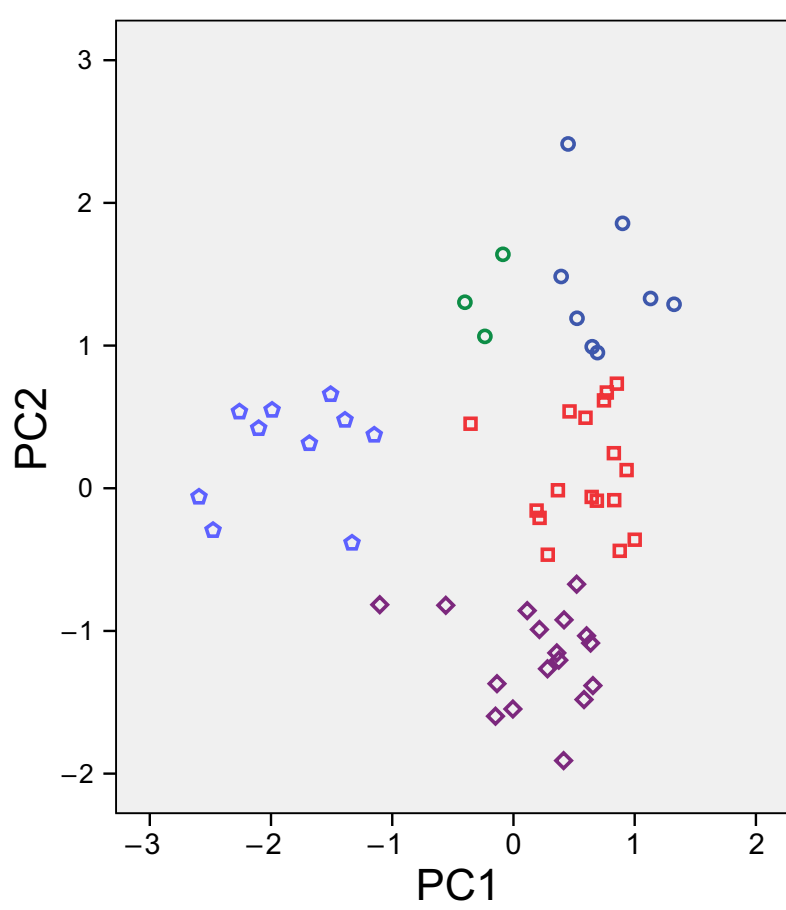

\section{- Alpine Thrush Z. mollissima Him + Sich \\ - Alpine Thrush/"Yunnan Thrush" Yun \\ - Himalayan Forest Thrush Z. salimalii \\ $\diamond$ Sichuan Forest Thrush Z. griseiceps \\ - Long-tailed Thrush Z. dixoni}

Fig. 13 Scatter plot of principal component analysis of four song variables (duration, top frequency, bottom frequency, frequency bandwidth and peak frequency of strophes) of the Z. mollissima-Z. dixoni complex. The birds labelled 'Alpine Thrush/"Yunnan Thrush" Z. mollissima (?) Yun' were only observed in the field and their identification was therefore not confirmed by molecular markers

nodes (Fig. 14). The MrBayes cytb tree, ND2 tree, concatenated cyt $b+\mathrm{ND} 2$ tree and tree based on all four concatenated loci inferred clades A-CD with PP 1.00; the sister relationship between clades $\mathrm{AB}$ and $\mathrm{CD}$ found in the BEAST cyt $b$ tree as well as a sister relationship between these and $Z$. dixoni received strong support in the cyt $b+\mathrm{ND} 2$ tree (PP 0.97) and in the four-locus tree (PP 1.00; Additional file 6: Figure S1). The myo and ODC trees as well as the concatenated myo + ODC tree supported the Alpine, Himalayan Forest and Sichuan Forest Thrush clades, but although the "Yunnan Thrush" formed a clade in these three trees, it was nested within the Himalayan + Sichuan Alpine Thrush clade; the sister relationship between $Z$. dixoni and the $Z$. mollissima complex was strongly supported in the myo + ODC tree (PP 1.00; Additional file 7: Figure S2).

The cytb chronogram (Fig. 14) estimated the age of clade $\mathrm{AB}$ to 4.6 (95 \% HPD 3.4-5.9) million years ago (mya) and clade CD to 4.9 (95 \% HPD 3.7-6.2) mya. The "BEAST ages for the same clades were 3.7 (95\% HPD 2.3-5.1) mya and 4.5 (95 \% HPD 3.4-5.6) mya, respectively (Fig. 14).

Mean pairwise uncorrected cytb distances among the four main clades of Z. mollissima s.l. were 6.7-9.6\%, whereas the same distances between $Z$. dixoni and any of the taxa in the Z. mollissima complex were 7.3-9.4\% (Table 4). Intrataxon divergence was $0.0-1.0 \%$ (Table 4); the highest value was between two individuals of Himalayan Forest Thrush. In comparison, the divergence between $Z$. aurea and $Z$. andromedae was $6.9 \%$.

\section{Habitat and behaviour}

In the Himalayas, we found the Alpine Thrush to breed above the tree limit $(\geq 4200 \mathrm{~m}$ a.s.l. at Sela pass and $\geq 4000 \mathrm{~m}$ a.s.l. in Kedarnath, Uttarakhand, India), on stony ground covered with mosses and lichens, short grass, various low herbs and scattered dwarf rhododendrons, and rocks and boulders of varying size (Fig. 15a). The taxon Z. m. whiteheadi was described to breed in northwest Pakistan on "rocky, treeless slopes at great altitude" [14,000 ft $(4270 \mathrm{~m})]$, with a nest found "in cleft in cliff" according to labels in the BMNH. Specimens of Alpine Thrush from the breeding season (June-August) with elevation label data were collected at 3353-4420 m a.s.l. (mean $3879 \mathrm{~m} \pm \mathrm{SD} 372 \mathrm{~m} ; n=8$ ). In the nonbreeding season, the Alpine Thrush appears to favour feeding in fairly open areas, such as pastures bordering forest and forest glades. Specimens of Alpine Thrush from the non-breeding season (September-April) with elevation label data were collected at 300-3505 m a.s.l. (mean $2107 \mathrm{~m} \pm$ SD $728 \mathrm{~m} ; n=20$ ). 


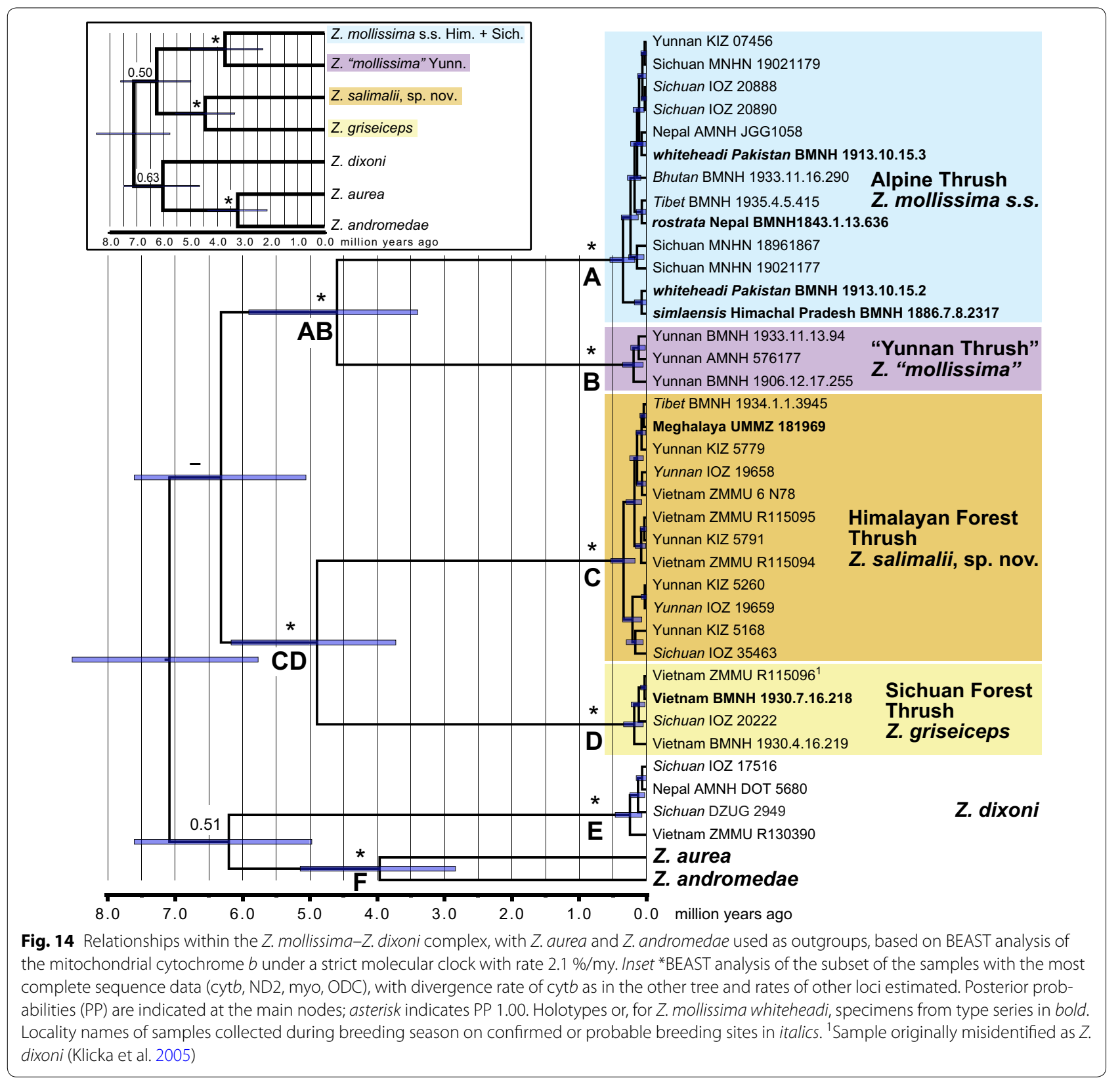

In Sichuan Province, China we confirmed the Alpine Thrush to breed on Niubei Shan at 3480 to ca. $3700 \mathrm{~m}$ a.s.l., just above the tree limit, on steep cliff faces with scrub and adjacent alpine meadows (Fig. 15b). One individual that was probably of this taxon (song heard briefly) was observed on Gongga Shan, Sichuan by P.A. in June 2012 at $4200 \mathrm{~m}$ a.s.l. in similar habitat as in the eastern Himalayas. Three singing males of Alpine/"Yunnan" Thrush were heard by P.A. and C.Z. in alpine habitat at $4600 \mathrm{~m}$ a.s.l. on Meilixue Shan, Yunnan Province, China on 5 June 2014 (Fig. 15c), and a pair with fledged young were observed just above the tree limit at $3500 \mathrm{~m}$ at Dulongjiang, Yunnan on 13-14 June 2014 by P.A., C.Z. and Jian Zhao (Fig. 15d; see "Song" section).

We have observed the Himalayan Forest Thrush in the eastern Himalayas in old coniferous forest with some rhododendrons and other broadleaved trees and lush undergrowth of scrub and herbs at 3430-3800 m a.s.l., exceptionally up to the tree line at $4200 \mathrm{~m}$ a.s.l. (Fig. 15e). We have also observed the Himalayan Forest Thrush in West Bengal, India at approximately 3200-3650 m a.s.l. In addition, we have obtained one recording (by Paul I. 
Table 4 Pairwise cytochrome $b$ distances (uncorrected $P$; \%) between some of the taxa in the Z. mollissima-Z. dixoni complex

\begin{tabular}{ll}
\hline & Uncorrected $\boldsymbol{P}$ \\
\hline Intrataxon & $0.4 \pm 0.2(0.0-1.0)$ \\
Alpine Thrush-“Yunnan Thrush" & $6.9 \pm 0.1(6.7-7.1)$ \\
Himalayan Forest Thrush-Sichuan Forest Thrush & $7.5 \pm 0.2(7.3-7.9)$ \\
Alpine Thrush/“Yunnan Thrush"-Himalayan Forest & $8.3 \pm 0.7(6.7-9.6)$ \\
$\quad$ Thrush/Sichuan Forest Thrush & \\
Z. mollissima s.l.-Z. dixoni & $8.5 \pm 0.6$ (7.3-9.4) \\
Z. aurea-Z. andromedae & 6.9
\end{tabular}

Values given are mean $\pm S D$ and, in parentheses, range

Holt) from central Bhutan at $3390 \mathrm{~m}$ a.s.l. At Dulongjiang, Yunnan Province, China, we found Himalayan Forest Thrush to be numerous in a very different habitat: on steep slopes with bamboo and rhododendron scrub and rocky outcrops and a few scattered conifers, at or just above the upper tree limit, at $3350-3500 \mathrm{~m}$ a.s.l. (Fig. 15d). Surprisingly, we did not observe any birds in the seemingly suitable forest immediately below despite active searching. On Cang Shan, Dali, Yunnan Province, China, C.Z. observed two singing males (and sound recorded one) on 21 May 2013 in fir (Abies delavayi) forest with some rhododendron mixed in at ca. $3850 \mathrm{~m}$ a.s.l. In the non-breeding season, the Himalayan Forest Thrush appears to favour dense broadleaved forest; only five specimens of this taxon have elevational label data, ranging from 1439 to $3200 \mathrm{~m}$ a.s.l. in the non-breeding season (September-April).

The habitat choice of the Sichuan Forest Thrush is somewhat variable. On Jiuding Shan and in Wolong, we have found it in dense secondary broadleaved forest with scattered conifers, and dense undergrowth of scrub (e.g. Ilex), rhododendron and bamboo, though in both Wolong and on Emei Shan it seems to favour forest with predominantly conifers, with some mixed-in broadleaved trees, and dense undergrowth of scrub and bamboo (Fig. 15g). At Jiuding Shan, we found it at $2630-3000 \mathrm{~m}$ a.s.l. (Fig. 15f); at Longcangguo at $2130 \mathrm{~m}$; in Wolong (including observations by Paul I. Holt and James Eaton, in litt.) at 2570-3120 m a.s.l.; and on Emei Shan (including one observation by Paul I. Holt, in litt.) at ca. 2500$3300 \mathrm{~m}$ a.s.l. The recordings that we have obtained from Wawu Shan are from ca. $2750 \mathrm{~m}$ a.s.l. (Lei Zhu, in litt.). The non-breeding habitat appears to be similar to that of the Himalayan Thrush. Only two non-breeding season (November) specimens of griseiceps have elevational label data, of 1067 and 1370 m a.s.l. respectively.

Zoothera dixoni breeds both inside coniferous and mixed forest and in rhododendron, Ilex and other scrub just above the upper tree limit. In Sichuan, we have observed it at ca. 3000-3800 m a.s.l., in the eastern Himalayas at ca. $4025 \mathrm{~m}$ a.s.l. and in Himachal Pradesh at ca. 3200-3300 m a.s.l.

The Alpine Thrush is rather easily observed, as it occurs in open habitats, at least on the breeding grounds, and is often very confiding. It usually sings from an exposed perch, such as a boulder. In contrast, the Himalayan Forest and especially Sichuan Forest Thrushes are both exceptionally secretive and shun open areas, and consequently are extremely hard to observe. Even when singing, they often stay well concealed inside the foliage of trees. However, at Dulongjiang, Yunnan Province, China, Himalayan Forest Thrush was fairly easily observed, as it often perched on top of a small conifer, a bamboo culm or rocky outcrop when singing. Z. dixoni is also secretive, but can often be observed feeding in semi-open areas inside forest or along trails and roads.

\section{Geographical distributions}

All of the verified observations that we have evaluated are plotted on the map in Fig. 1. Based on morphological and genetic evidence, the Alpine Thrush breeds in the Himalayas from northern Pakistan through the eastern Himalayas, and in Sichuan Province, China. This is further supported by sound recordings from Uttarakhand, northwest India through the eastern Himalayas, and from Sichuan. It is unknown whether the apparent distributional gap between the eastern Himalayas and Sichuan is real or just represents a gap in our knowledge. Field observations show that Alpine type birds, possibly representing "Yunnan Thrush", breed in northwest Yunnan Province, China. As the only known specimens of "Yunnan Thrush" are from western Yunnan in the non-breeding season, we have no further indications of its breeding area. In the Himalayas, the Alpine Thrush descends to lower elevation in the non-breeding season. Alpine Thrushes breeding in Sichuan probably winter further south; there is one specimen, confirmed by DNA, from Lijiang, Yunnan on 22 October (KIZ YL07456). Alpine Thrushes (pehaps including "Yunnan Thrushes") are regularly observed on spring and autumn migration in Sichuan, e.g. several small loose flocks of usually 2-3 birds, altogether c. 40 individuals, along a c. $10 \mathrm{~km}$ stretch of road between Moxi and Kangding (from $29^{\circ} 47.919^{\prime} \mathrm{N}, 102^{\circ} 3.710^{\prime} \mathrm{E}$ to $29^{\circ} 51.693^{\prime} \mathrm{N}, 102^{\circ} 2.101^{\prime} \mathrm{E}$ ) on 19-20 April 2012 (Sid Francis, in litt.; identification confirmed by photos by Augusto Faustino of some of these).

Based on morphological, vocal and genetic data, Himalayan Forest Thrush breeds from Sikkim and Darjeeling, India, to northwest Yunnan. In addition, we have examined a single specimen (IOZ 35463) from south Sichuan, China, collected during the breeding season (10 May 


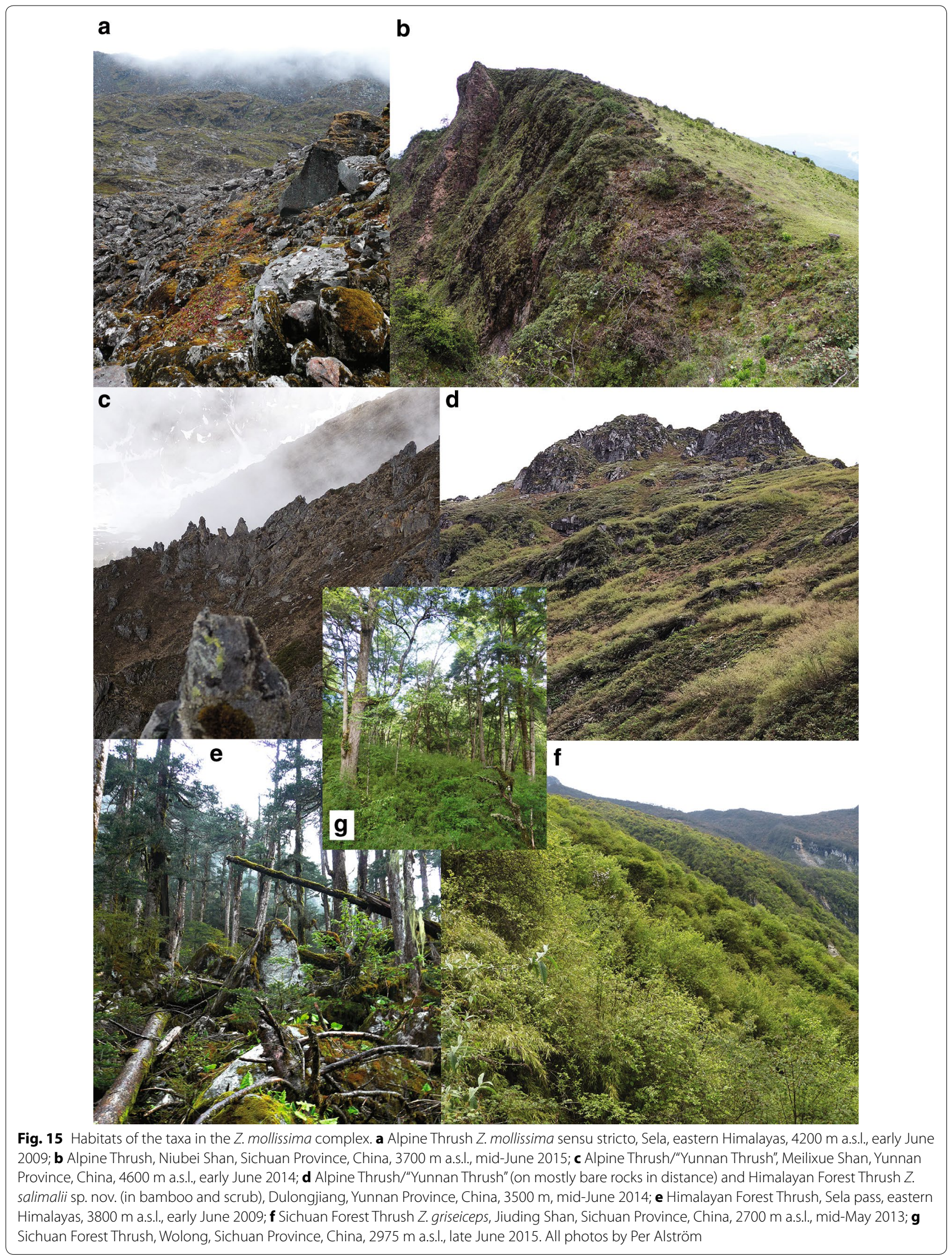


1960), and a 7 May 1972 bird (KIZ 72183) from Luchun County, SE Yunnan; these birds may have been migrants or on their breeding grounds. We do not know whether the distribution is continuous or patchy. It descends to lower elevation in winter, and there are non-breeding period records from as far south as Meghalaya and Manipur (although the precise localities within the latter state were not located), India and northern Vietnam.

The breeding range of Sichuan Forest Thrush appears to be restricted to central Sichuan (Fig. 1). This is based on morphology, song and DNA from a single individual from Jiuding Shan (Figs. 5, 12) as well as multiple field observations from other localities. There are two specimens from Emei Shan (USNM 317393, 317394), within the breeding range, but they were collected on 8 and 19 November, respectively; all other specimens were collected in north Vietnam in the non-breeding season.

Zoothera dixoni breeds sympatrically with all three Z. mollissima s.l. taxa, as well as with Alpine Thrush/"Yunnan Thrush" in Yunnan. The Alpine and Himalayan Forest Thrushes are probably sympatric throughout the latter's breeding range in the Himalayas, although proof of this exists only for the eastern Himalayas, where they are locally syntopic (though segregated by altitude and habitat). Alpine Thrush/"Yunnan Thrush" was found breeding in sympatry with Himalayan Forest Thrush at Dulongiiang, Yunnan, and they were occasionally seen within a few meters from each other (but in different habitats; see above and Fig. 15). Sichuan Forest Thrush is not known to be syntopic with any of the others, but it seems very likely that it occurs on some of the same mountains as Alpine Thrush. Although no Alpine Thrushes have been found breeding in Wolong, where Sichuan Forest Thrush breeds, there are extensive areas of seemingly excellent Alpine Thrush habitat there, and we have seen photos of Alpine Thrushes on migration through Wolong, so it seems very possible that both species breed there. Also at Jiuding Shan, where Sichuan Forest Thrush is fairly common, there is plenty of seemingly excellent but essentially unsurveyed breeding habitat for Alpine Thrush.

\section{Discussion}

\section{Taxonomy}

The morphological (both plumage and measurements), vocal, mitochondrial, nuclear and ecological data congruently separate the $Z$. mollissima-Z. dixoni complex into four groups, corresponding to $Z$. dixoni and the three Z. mollissima s.l. taxa here referred to as Alpine Thrush, Himalayan Forest Thrush and Sichuan Forest Thrush. Mitochondrial DNA, weakly supported by the two nuclear markers, also identify a putative taxon, "Yunnan Thrush", so far only known from three old museum specimens collected in the non-breeding season in Yunnan. The divergences among these lineages date back several million years, and predate the split between $Z$. aurea and $Z$. andromedae. The cyt $b$ divergence between $Z$. dixoni and any of the $Z$. mollissima s.l. taxa is close to the divergences among the $Z$. mollissima s.l. taxa. Moreover, at least two, perhaps even three, of the taxa are locally sympatric, though ecologically separated.

Zoothera dixoni is the most distinctive taxon, differing from the others in plumage, structure and song, and is genetically distinct from the others. Moreover, it is sympatric with the Alpine, Himalayan Forest and Sichuan Forest Thrushes, although it is perhaps completely segregated from the first-mentioned by habitat/elevation. The Alpine Thrush differs from the Himalayan Forest and Sichuan Forest Thrushes by plumage, morphometrics and song, and has been separated from the two others for at least 5 my (minimum value of $95 \%$ HPD for cyt $b$ and "BEAST analysis). Moreover, the Alpine and Himalayan Forest Thrushes are sympatric in the eastern Himalayas, where they breed in different habitats at different altitudes. There is no evidence of any overlap between them in breeding habitat and, for example, in June 2009 at Sela pass, P.A. and S.D. once heard an Alpine Thrush and a Himalayan Forest Thrush singing at the same time, the former in the alpine habitat above the tree limit and the latter in the forest below. Although there is no proof yet of sympatry between Alpine and Sichuan Forest Thrushes, it seems likely that they are locally sympatric, but occurring in different habitats at different elevations.

Alpine Thrushes from Sichuan are larger than Himalayan ones. The three specimens of the putative taxon "Yunnan Thrush" that were identified genetically are deeply diverged from their sister taxon Alpine Thrush from the Himalayas + Sichuan, although they are morphologically indistinguishable from Alpine Thrushes from Sichuan. The chance that the "Yunnan Thrush" sequences are nuclear paralogs ("numts") is minimal, as they were amplified in short (ca. 100-200 bp), partly overlapping fragments; no stop codons or indels were found; the cyt $b$ and ND2 trees were congruent; these two genes were similarly divergent; and the nuclear sequences were also divergent, although the "Yunnan Thrush" clade was nested within the Himalayan + Sichuan Alpine clade. We hypothesize that our recordings of song of Alpine type birds from Yunnan, which differ from songs of Alpine Thrushes from the Himalayas and Sichuan, represent "Yunnan Thrush", although future studies are required to confirm or refute this, and also to confirm whether the vocal differences are consistent, as our sample sizes from Yunnan and Sichuan are small.

The Himalayan Forest Thrush and Sichuan Forest Thrush differ subtly, but noticeably, in plumage, and 
strongly in morphometrics. Although their songs are fairly similar, they are audibly different, and all of the individuals in our sample were completely separated in the vocal PCA and DFA. They are sisters, although they were estimated to have diverged at least 3.4 mya (minimum value of $95 \%$ HPD for cyt $b$ and "BEAST analysis), and the cyt $b$ distance between them is substantial (7.5 \%-higher than between Z. aurea vs. Z. andromedae, $6.9 \%$ ). Moreover, although both taxa inhabit forests, their habitat preferences differ, at least on average. On present knowledge, they are allopatric, although their ranges come into fairly close contact.

The above results suggest that $Z$. mollissima s.l. should be considered at least three distinct species, and $Z$. dixoni should continue to be recognized at the species level. We have been unable to trace the holotype of Turdus mollissimus Blyth, 1842 (=Z. m. mollissima) from Nepal, although based on the description and measurements given in the original description we are convinced that this refers to the Alpine Thrush, which should therefore be referred to as Z. mollissima sensu stricto (s.s.) (see "Appendix"). Also Oreocincla whiteheadi Baker, 1913 (=Z. m. whiteheadi), Oreocincla mollissima simlaensis Baker, 1924 (=Z. m. simlaensis) and Oreocincla rostrata Hodgson, 1845 are Alpine Thrush according to our morphological and genetic analyses of type material of these (see "Appendix"). The same applies to Turdus hodgsonii von Homeyer, 1849 and Turdus oreocincloides Hodgson in Gray, 1844 based on morphological data (see "Appendix"). Thus, all these names refer to Z. mollissima s.s.

We have not found any name that applies to the "Yunnan Thrush", but as this putative taxon is presently just identified by DNA sequences from three old museum specimens, we refrain from naming it until its distinctness can be verified by independent data. In contrast, morphology and DNA from type material of Oreocincla griseiceps Delacour, 1930 (=Z. m. griseiceps) match Sichuan Forest Thrush, which should therefore be called Z. griseiceps.

We do not consider the weakly marked subspecies whiteheadi (of which simlaensis is a synonym) worthy of recognition, because (as with a great many other Himalayan taxa) the color differences are weak, variable, and clinal, and no other differences have been detected.

As we have not been able to find any name that unambiguously applies to the Himalayan Forest Thrush, we describe this as a new species:

\section{Zoothera salimalii, sp. nov.}

Holotype. UMMZ 181969, adult male, Mawphlang, Khasi Hills, Meghalaya, India, collected on 21 January 1954 by Rupchand. Measurements of holotype: culmen (mm) from skull base 30; culmen from distalmost feathers 22; wing (flattened) 140 (same measurement for unflattened wing); tail 97; tarsus 34.2. Specimen is in fairly fresh plumage, but is missing numerous feathers from the left side of the face. GenBank numbers: KU195755 (cytb), KU195781 (myo) and KU195814 (ODC).

\section{Diagnosis of species}

Zoothera salimalii is similar to Z. mollissima (s.s.), $Z$. griseiceps, and to a lesser extent $Z$. dixoni, but is diagnosably distinct from each on multiple characters. Compared to Z. mollissima, Z. salimalii has a noticeably longer and deeper bill, with more arched culmen and longer hook, and the lower edge of the lower mandible is more arched (vs. straight); bill usually completely or almost completely dark including base of lower mandible, whereas the base of the lower mandible is usually pale pinkish or yellowish in Z. mollissima (though may appear mainly dark also in Z. mollissima). Rictal bristles of Z. salimalii are typically longer, thicker, and blacker, and therefore more prominent, than in Z. mollissima. Z. salimalii has shorter wings, shorter primary projection, shorter tail, and shorter tarsi, with a larger bill and a relatively (not absolutely) longer hindclaw than does Z. mollissima. Z. salimalii typically has denser, fluffier more extensive narial feathering compared to $Z$. mollissima.

Most individuals of $Z$. salimalii have a thin whitish supraloral stripe over thick blackish lores, and a very dark subocular/moustachial area, more or less connected to the dark lores, compared to more diffuse pale supraloral and weak "salt-and-pepper" lores and subocular/moustachial area of $Z$. mollissima. Also, Z. salimalii usually shows less extensively pale-mottled ear-coverts than in Z. mollissima, especially on the upper part, and lacks or has only a very ill-defined dark spot on the rear earcoverts, while $Z$. mollissima usually shows a distinct dark rear ear-covert patch. $Z$. salimalii is usually ruddier in color above than $Z$. mollissima. Z. salimalii usually has indistinct, narrow dull buffy tips to secondary coverts (not white or pale buff, often fairly distinct, tips as in $Z$. mollissima). Z. salimalii has weak, dull rufescent primary edgings, darker than in $Z$. mollissima, in which these are pale dull buffy. Z. salimalii has clearcut small white tail wedges at the tips of the two outermost pairs of rectrices, not diffuse patches on the outermost pair of rectrices nor (usually) white edges at the tip of the second outermost pair of rectrices like those typical of $Z$. mollissima. The central rectrices (R1) of $Z$. salimalii are darker and thus contrast (usually) much less with the blackish rectrices R3-R5 than in Z. mollissima, noticeably only from above when tail is spread. $Z$. salimalii, unless in very worn plumage, has an overall strong buffy suffusion on underparts, not just the breast as in most $Z$. mollissima; the buffy suffusion usually includes central underparts 
in $Z$. salimalii, which is never the case in Z. mollissima. $Z$. salimalii has a narrow, almost unmarked golden-buff throat (whiter when worn) bordered by strong black malar, while in Z. mollissima the throat is usually whiter and generally more heavily marked (often much more so) and less strongly bordered by more diffuse malar stripes. $Z$. salimalii has the claws paler than the toes, lacking dusky areas, while in $Z$. mollissima the claws are at least partly darker than or similar in color to the toes. The legs of $Z$. salimalii are pinkish, while those of $Z$. mollissima are usually brighter and more yellow- or orange-tinged.

Compared to Z. griseiceps, which appears proportionately smaller-billed than $Z$. salimalii owing to its larger head and overall size, $Z$. salimalii appears dumpy due to its shorter tail and legs than in Z. griseiceps. The crown of $Z$. salimalii is more rufous and plainer, not distinctly darker and greyer than mantle or with fairly prominent scalloping as in many $Z$. griseiceps. The nape of $Z$. salimalii is only slightly paler than crown, not distinctly paler as in some $Z$. griseiceps. The auriculars of $Z$. salimalii are blotchier, with distinct dark and light areas, while in $Z$. griseiceps the auriculars are more finely and uniformly streaked whitish, and the lores and subocular/moustachial areas of salimalii are darker and more contrasting than those of griseiceps (which has the least contrastingly patterned face of all taxa in the complex).

Compared to $Z$. dixoni, $Z$. salimalii has a much larger, heavier bill, and much shorter tail and tarsi. Z. salimalii also has much more uniform auriculars, wing coverts, primary coverts, and primary edgings, with a more heavily marked, less extensively white belly and undertail coverts, and more crescentic, less thick dark markings with less straight "upper" edges on the flanks than $Z$ dixoni. The underside of the tail has more contrasting and smaller white patches in $Z$. salimalii than in $Z$. dixoni.

The bill of $Z$. salimalii is strikingly similar in form to that of Dark-sided Thrush Zoothera marginata, though not as long, and not as broad near the tip. In Z. salimalii, the bill typically appears to be slightly downcurved at the tip, unlike all the other taxa in the $Z$. mollissima complex.

Zoothera salimalii is identifiable by both cyt $b$ (GenBank KU195748-KU195759), ND2 (GenBank KU195790), myo (GenBank KU195777-195783) and ODC (GenBank KU195810-KU195814).

\section{Description of holotype}

Color designations are from Munsell Color (2000) and Smithe (1975). Bill large, long, heavy, with strong subterminal notch on culmen and long curved hook distal to notch; proximal culmen ridge arched; bill blackishbrown, vaguely paler near notch, cutting edge, and base of lower mandible from below, with proximal cutting edges narrowly and contrastingly yellowish. Rictal bristles thick, profuse, and black for their entire exposed lengths. Upperparts from forehead to rump uniform dark russet-brown (5YR 4/2), slightly paler and more olive (7.5YR 4/3) on hindneck and rump. Uppertail coverts darker (7.5YR 3/3), narrowly edged paler olive-brown (7.5YR 4/3).

Supraloral pale fulvous, slightly mottled but distinctly paler and brighter than feathering above it, and bordered below by nearly solid black loral stripe. Eye-ring fairly narrow (mainly one row of tiny feathers), buff-tinged, and many of eye-ring feathers have tiny dark basal, central, and/or tip inclusions that make the eye-ring not especially well-marked. Auriculars (intact on right side but with many feathers missing on left side, hence this description of auriculars, moustachial, and malar regions refers solely to right side) mostly dark and not very contrasting, but with pale buff shaft streaks on most feathers (not uppermost ones), coalescing to a paler buff area at lower rear auriculars, and a blacker area at lower anterior edge, merging with heavy blackish moustachial line. Narrow pale buff submoustachial with fine blackish-brown feather edgings, and broad blackish malar stripe composed of blackish triangular marks on feathers coalescing into a stripe. Chin buffy-white, rest of throat pale buff (Cream Color, Color 54), with tiny and faint (mid-throat) to rather small but well-marked (lower throat) dark feather edgings in the form of short bars, becoming more triangular on a few feathers of the lower throat sides.

Breast strongly buffy (10YR 8/4), the buffy tinge carrying over onto flanks, where it is weaker, and with a slight buffy tinge over the remainder of underparts except undertail coverts. Breast has heavy blackish-brown scaly markings (terminal bars) about $2-3 \mathrm{~mm}$ at widest point, on upper breast markings mostly with a straight upper border and curved lower border (feather tip). Towards lower breast, these become slightly more v-shaped. On the flanks, dark marks become slightly more rounded, with dark tip even-width for most of its length and pale area impinging farther distally on feather centers, especially along shaft. Central belly buffy-white with tiny to fairly small, sparsely and irregularly spaced dark feather tips. Undertail coverts appear mainly whitish, with dark feather edges showing through on most and on longest undertail coverts with dark brown feather edgings covering about $1 / 3$ of webs and ending about $7 \mathrm{~mm}$ from feather tip.

Wing concolorous with mantle; secondary coverts and tertials with barely discernible if any paler fringes; primary tips duller, duskier, darker brown than tertials. Primary coverts slightly paler and brighter than secondary coverts (7.5YR 5/4), broadly tipped blackish brown. 
Primary edgings broadly paler rufous-brown (7.5YR $6 / 4)$, rest of each of primaries much darker brown. Well-marked, broad, pale buff underwing stripe through remiges.

Upper surface of central rectrices slightly darker brown than uppertail coverts (7.5YR 3/2), and upper surface of other rectrices even darker (7.5YR 3/1). Rectrices (R) 3-6 (numbered from central pair) have sharply demarcated white tips, that of R3 tiny and restricted to distal $2 \mathrm{~mm}$ of rectrix centered around protruding shaft tip, white tip of R4 slightly larger (3 $\mathrm{mm}$ long at shaft tip, and coalescing with very narrow white edge on entire distal tip of feather); white tip of R5 larger ( $7 \mathrm{~mm}$ long $\times 8 \mathrm{~mm}$ wide, and almost evenly centered over inner distal outer web and outer distal inner web), and that of R6 much larger (29 $\mathrm{mm}$ long along shaft and $13 \mathrm{~mm}$ wide, white much narrower near internal feather edge but a very narrow white edge on feather edge more than half-way to the feather insertion point; white tip of R6 almost entirely restricted to inner web. Underside of rectrices very dark brown except for sharply defined white tips. Six pairs of rectrices.

Soft part colors not recorded. Legs of dried specimen dark fleshy, claws distinctly paler than toes and lacking dark tips.

\section{Plumage variation}

The type differs slightly from most other specimens of $Z$. salimalii in having a less well-demarcated, darker supraloral area. In most specimens of $Z$. salimalii, this is a narrow, clear whitish stripe over the broad blackish loral stripe. The type also differs from several other specimens of $Z$. salimalii in its near-complete lack of buff edges to the secondary coverts. Bill size is notably variable in this species, with many specimens showing the obviously large, arched bill, while a few others appear intermediate in bill size and shape with Z. mollissima s.s.

\section{Etymology}

We name this new species for Dr Sálim Ali, in honor of his huge contributions to the development of Indian ornithology and conservation.

\section{Nomenclatural acts}

This work represents a marginally modified version of an earlier published work that was registered in ZooBank with the LSID urn:lsid:zoobank.org:pub:4395ADCD469B-4D2D-8DFE-27A2EA5DA489, which was available on 20 January 2016.

\section{Status and conservation of all taxa}

As the Alpine Thrush is widely distributed and its habitat is not under threat, it should be considered as being of least concern. Z. salimalii is locally common in the eastern Himalayas, and locally abundant at Dulongjiang, Yunnan Province, China. Because it is widely distributed and its habitat is not under any imminent threat (other than forest areas in general), it should be considered as being of least concern. Zoothera griseiceps is only known to breed in a rather small area in Sichuan Province, China. However, as it is locally fairly common, and occurs in several protected areas, it is probably not under any imminent threat, at least not on its breeding grounds.

\section{Conclusion}

Based on analyses of plumage, morphometrics, mitochondrial and nuclear DNA, song, breeding habitat and geographical distributions, we conclude that $Z$. mollissima s.l. should be split into at least three species, one of which is described here as a new species: Alpine Thrush Z. mollissima s.s., Himalayan Thrush Z. salimalii (sp. nov.) and Sichuan Forest Thrush $Z$. griseiceps, all monotypic. In addition, a distinct lineage, "Yunnan Thrush", was identified genetically, but as we have no corroborating evidence that it is distinct from Alpine Thrush,

\section{Table 5 English and scientific names (including synonyms), and type status, of taxa in the Z. mollissima complex}

\begin{tabular}{|c|c|c|c|}
\hline English name & Scientific name & Type status & Determination \\
\hline Alpine Thrush & mollissima & Type not found (ZSI?) & Z. mollissima \\
\hline Alpine Thrush & rostrata & Selected type studied; lectotypified herein (BMNH) & Z. mollissima \\
\hline Alpine Thrush & oreocincloides & nomen nudum (BMNH) & Z. mollissima \\
\hline Alpine Thrush & hodgsonii & Type studied (ZMMU) & Z. mollissima \\
\hline Alpine Thrush & simlaensis & Type studied (BMNH) & Z. mollissima \\
\hline Alpine Thrush & whiteheadi & Type studied (BMNH) & Z. mollissima \\
\hline Sichuan Forest Thrush & griseiceps & Type studied (BMNH) & Z. griseiceps \\
\hline Himalayan Forest Thrush & Named herein & Type selected herein (UMMZ) & Z. salimalii, sp. nov. \\
\hline "Yunnan Thrush" & Undescribed & - & $?$ \\
\hline Pied Thrush & micropus & Type not found (BMNH) & Z. wardii \\
\hline
\end{tabular}

Museum acronyms in "Methods" section 
we refrain from describing it here. $Z$. dixoni should be retained as a distinct species. See Table 5 .

\section{Additional files}

\section{Additional file 1: Table S1. Samples used in the genetic analyses, including GenBank numbers.}

Additional file 2: Data S1. Alignments of all sequences.

Additional file 3: Data S2. Xml file for BEAST analysis of cytochrome $b$.

Additional file 4: Data S3. Xml file for *BEAST analysis of all loci.

Additional file 5: Table S2. Output from PCA and DFA on song variables.

Additional file 6: Figure S1. MrBayes analyses of cytochrome b, ND2, concatenated cytochrome $b+\mathrm{ND} 2$ and all loci concatenated.

Additional file 7: Figure S2. MrBayes analyses of myoglobin, ODC and concatenated myoglobin + ODC

\begin{abstract}
Authors' contributions
The original planning was done by PA, PCR, and UO. In addition, PA collected DNA samples, sound recordings, morphometrics and other data in the field, and carried out the vocal and phylogenetic analyses; PCR collected and analysed the morphological data; CZ and SD collected field data (in China and the Himalayas, respectively); JX measured and statistically analyzed vocal variables; TC and YG sequenced the fresh samples from China; MK collected DNA samples and measured the specimens in ZMMU; UO sequenced all samples except the fresh Chinese samples; PA and PCR wrote the text. All authors read and approved the final manuscript.
\end{abstract}

\section{Author details \\ ${ }^{1}$ Department of Animal Ecology, Evolutionary Biology Centre, Uppsala Univer- sity, Norbyvägen 18D, 75236 Uppsala, Sweden. ${ }^{2}$ Key Laboratory of Zoological Systematics and Evolution, Institute of Zoology, Chinese Academy of Sciences, Beijing 100101, China. ${ }^{3}$ Swedish Species Information Centre, Swedish Univer- sity of Agricultural Sciences, Box 7007, 75007 Uppsala, Sweden. ${ }^{4}$ Department of Integrative Biology and MSU Museum, Michigan State University, East Lan- sing, MI 48864, USA. ${ }^{5}$ Bird Group, The Natural History Museum at Tring, Ake- man Street, Tring HP23 6AP, UK. ${ }^{6}$ Cloud Mountain Conservation, Dali 671003, China. ${ }^{7}$ Department of Evolutionary Biology, Evolutionary Biology Centre, Uppsala University, Norbyvägen 18D, 75236 Uppsala, Sweden. ${ }^{8}$ Researchers for Wildlife Conservation, F-21, National Centre for Biological Sciences, GKVK, Bellary Road, Bengaluru, Karnataka 560065, India. ${ }^{9}$ College of Life Sciences, University of Chinese Academy of Sciences, Beijing 100049, China. ${ }^{10}$ Zoologi- cal Museum of Lomonosov Moscow State University, Bolshaya Nikitskaya Str., 2, Moscow 125009, Russia. ${ }^{11}$ Systematics and Biodiversity, Department of Biology and Environmental Sciences, University of Gothenburg, Box 463, 40530 Göteborg, Sweden.}

\section{Acknowledgements}

We gratefully acknowledge the staff of the following museums for allowing access to the collections and in many cases loan of specimens under their care and/or collected by them: Paul Sweet, AMNH; Robert Prŷs-Jones and Mark P. Adams, NHMUK; Moe Flannery, CALAS; John Bates, David Willard, and Ben Marks, FMNH; He Peng, IOZ; Yang Xiaojun and Liu Luming, KIZ; Jeremiah Trimble, MCZ; Jérôme Fuchs and Patrick Bousses, MNHN; Laura Abraczinskas, MSUM; Helen James and Gary Graves, NMNH; Steven van der Mije, NNM; Claudia Kamcke and Bettina Borges-Naumer, SNMB; Diarmaid Ó Foighil and Janet Hinshaw, UMMZ; and Sylke Frahnert and Jurgen Fiebig, ZMB. In addition, DNA samples, including toepad samples, were provided by Joel Cracraft, Thomas Trombone and Paul Sweet, AMNH; Robert Prŷs-Jones and Mark P. Adams, NHMUK; Chen Jun and He Peng, IOZ; Yang Xiaojun, KIZ; Jérôme Fuchs, MNHN; and Diarmaid Ó Foighil and Janet Hinshaw, UMMZ. We are most grateful to Craig Brelsford, Liang Chen, James Eaton, Sid Francis, Paul Holt, Xiaonong Yang and Lei Zhou for providing sound recordings; and to Björn Anderson, Steve Bale, Garima Bhatia, Craig Brelsford, Vijay Cavale, George Chapman, Li Cheng, Ranjan Kumar Das, Augusto Faustino, John and Jemi Holmes, Yann Muzika, Sachin Rai, Pranjal Saikia, Takema Saitoh, Subrato Sanyal, Adesh Shivkar, Nitin
Srinivasmurthy, Rajneesh Suvarna, Ulrich Weber and Huaming Zhou for providing photos. We gratefully acknowledge Robert Prŷs-Jones for providing considerable information on types; Edward C. Dickinson for providing extensive background information on collections and specifically on some of the types involved; Effie Warr for information on types history; Richard Schodde for providing further advice on typification and nomenclature; Tom Versluijs for providing help on statistical analysis; Peng Li, Jian Zhao and Min Zhao for field assistance; Sid Francis and Roland Zeidler for various information; René Pop for editing some photos for figures; Yang Liu for various assistance, including collecting of photos and locality information and for help with data collection at KIZ; Gobinathan Maheswaran, Zoological Survey of India and Pramod Nair, Salim Ali Centre for Ornithology and Natural History for providing information on specimens; and WU Fei of KIZ for translating and providing information on localities of specimens. We gratefully acknowledge partial financial support from the Ministry of Science and Technology of China (Grant No. 2014FY210200, to. T.C. and Y.G.), the Russian Science Foundation (Project No. 14-50-00029, to M.K.), the Delia Koo Global Faculty Endowment of the Asian Studies Center, Michigan State University (to P.C.R.), The Sound Approach and Jornvall Foundation (both to P.A. and U.O.), the Chinese Academy of Sciences Visiting Professorship for Senior International Scientists (No. 2011T2S04, to P.A.) and Swarovski Optik Greater China (to P.A.).

\section{Competing interests}

The authors declare that they have no competing interests.

\section{Appendix: The identity of Turdus mollissimus Blyth, 1842, Oreocincla rostrata Hodgson, 1845, Turdus hodgsonii von Homeyer, 1849 and Turdus oreocincloides Hodgson in Gray, 1844}

The identity of Turdus mollissimus Blyth, 1842

The history of the type specimen of the oldest available name, T. mollissimus Blyth, 1842 has been obscured by misinformation. The specimen described by Blyth has been assumed to have been part of a collection from Darjeeling made by J. T. Pearson (Curator of the Asiatic Society's collection some years before Blyth (Sclater 1892; Seebohm et al. 1898); and if so should have been among those given to the Hon. East India Company's (HEIC) collection in 1842 (Edward Dickinson in litt. 9 July 2011). There were indeed two specimens of this taxon in the HEIC (Horsfield and Moore 1854), but neither was therein indicated as a type. The HEIC collection was dispersed among British collections (Edward Dickinson in litt. 9 July 2011) and Blyth's type has never surfaced.

However, the statement by Seebohm et al. (1898) that Blyth described a Pearson specimen for Z. mollissima is evidently erroneous. Sclater (1892) listed two B. H. Hodgson Nepal specimens as types of Turdus mollissima, Blyth, J. A. S. B., xi. p. 188, in his type-list for the Indian Museum [now Zoological Survey of India (ZSI), Calcutta]. Blyth (1842) specifically stated "A highly interesting collection of bird-skins, from Darjeeling, having been kindly entrusted to my charge by Dr. Pearson, for the purpose of describing, or otherwise noticing such among them as I may consider to be new, or worthy of some remark, I avail myself of the occasion not only to respond to the wishes of that gentleman, but to record a variety of observations upon other Indian and Malayan species of birds, which have recently fallen under my 
notice." Indeed, many of the species described therein cannot have been from Darjeeling nor therefore from Pearson, so there seems no reason to doubt that the type of $Z$. mollissima was from Hodgson and is or was in the ZSI, as per Sclater's (1892) catalog. Unfortunately, all specimens from Blyth's time were exhibited until 1872, by which time they had suffered serious damage, and some (not including Z. mollissima) had already been lost by 1892 (Sclater 1892).

Blyth (1842) provided measurements of only one specimen (a female) and did not mention a second. A great many uncertainties attach to Hodgson types (Dickinson 2006). Fortunately, however, Blyth's (1842) detailed description of the female (which if found could likely be identified on measurements) allows us to identify the taxon to which the name mollissima pertains. Comparing his T. mollissimus with both White's Thrush Zoothera whitei and "the Mavis Thrush", by which he meant Redwing Turdus iliacus (Mavis Thrush usually referring to Song Thrush T. philomelos, but sometimes other British thrushes including T. iliacus (Greenoak 1997), the latter being specifically mentioned by Blyth), Blyth stated that his $Z$. mollissima approaches nearest to T. iliacus except in being considerably larger.

Assuming that Blyth's (1842) measurements (Table 1) were made similarly to those by P.C.R. here, the type of $Z$. mollissima matches female Alpine Thrush on univariate measurements (but with overlap with Himalayan Forest Thrush), and on a PCA (Fig. 2b) consistently clusters with female Alpine Thrush. However, on this limited external dataset we cannot rule out the possibility of Blyth's type being missexed, and/or of his measurements having been made differently than those by P.C.R., in which case on measurements it could be a small male of the Himalayan Forest Thrush.

However, Blyth (1842) stated that his T. mollissimus has the "[b]ill shaped as in the Mavis Thrush". This strongly supports the identity of mollissima with the Alpine Thrush, as the bills of all individuals of the Himalayan Forest Thrush we have studied are noticeably larger, heavier, more arched, and more hook-tipped than the bill of T. iliacus. It is scarcely conceivable that Blyth would have equated the bill shape of the Himalayan Forest Thrush with that of T. iliacus without further qualification of the obvious differences.

Further, Blyth's (1842) description of the upperparts color of his T. mollissimus "...of a uniform rich brown colour above, with a slight cast of orange, being very nearly that of the back of an English Robin..." also shows that the bird in question must have been an Alpine Thrush, as all individuals examined of the Himalayan Forest Thrush are distinctly much more reddish above than European Robin Erithacus rubecula.
Similarly, Blyth (1842) states of the tail, "the outermost pair albescent-brown with a whitish tip" fits well with nearly all Alpine Thrushes, but not with Himalayan Forest Thrush, which typically has strong contrast between the blackish-brown undertail and the white tips. His description "[b]ill dusky-yellowish at the base of the lower mandible..." fits well with most Alpine Thrushes, but not most Himalayan Forest Thrushes. Finally, Blyth's (1842) description “...the spots...being of a triangular form upon the [breast], the throat, and front of the neck..." is true of most Alpine Thrushes, some of which have strong triangular markings even on the central throat, but Himalayan Forest Thrushes have the throat marks obsolete or in the form of fine bars.

Considering all the above evidence, we are confident that the name T. mollissimus Blyth, 1842 refers to the Alpine Thrush, and there is no evidence that it represents the Himalayan Forest Thrush. We choose not to undertake neotypification in this case because: (following Art. 75.3; ICZN 1999) the identity of the species can be recognized from the original description; because the original type may still exist; and because there is no exceptional need for designation of a neotype of T. mollissimus Blyth, 1842.

\section{The identity of Oreocincla rostrata Hodgson, 1845}

This name, as far as we know, was used as a species only by Hodgson (1845), after which it was universally considered a synonym of mollissima Blyth, 1842 (Dickinson and Walters 2006). Although we have shown using DNA and morphology (Figs. 2, 14) that the type selected by R. Warren (Warren and Harrison 1971) for O. rostrata (BMNH 1843.1.13.636) is clearly the same taxon as the Alpine Thrush, type concepts were not well-established nor adhered to during Hodgson's time and for many years thereafter, and for species he named there is often no guarantee that the selected type is actually the bird Hodgson was describing. In the BMNH type-list (Warren and Harrison 1971), it was explicitly stated that the selection of a type does not constitute lectotypification. A specimen of Himalayan Forest Thrush (BMNH 1859.3.4.22) was labeled "Type of O. rostrata, Hodgs." and then annotated by Warren "Co [type], Another spec. is selected. Much doubt. R. W."

There are several lines of uncertainty involving the type status of the type specimen originally selected by Warren (Warren and Harrison 1971). For example, the measurements given by Hodgson (1845) do not closely fit measurements taken by P.C.R. of the selected type specimen nor others of the alpine mollissima group, but are close to the measurements of BMNH 1859.3.4.22 (Hodgson's measurement first, BMNH 1859.3.4.22 s, 


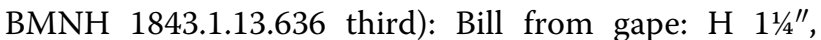
P.C.R. 1.29", 1.17"; wing: H 51/4", P.C.R. 5.23", 5.67"; tarsi: H 11/4", P.C.R. 1.35", 1.51"). Moreover, the original labels were long ago removed and replaced by BMNH staff (Sharpe 1906). However, BMNH 1843.1.13.636 is the only one of Hodgson's specimens now in the BMNH that was accessioned into the BMNH (the first four digits of the registration number are the year of registration) prior to Hodgson's (1845) description, while none of Hodgson's Himalayan Forest Thrushes were accessioned until 1859. The 1843 specimen would almost certainly have been available to Hodgson for his 1845 description, because Hodgson was in Britain in 1844 and 1845, and Hodgson's major collection that was assumed by the Grays to contain his types came into the museum from 1843 to 1845 (Dickinson 2006). We cannot know, however, whether other Hodgson specimens not now present in the BMNH were also available to Hodgson at this time, because many specimens were consigned to duplicates and/or distributed to other museums without careful records being kept (Dickinson 2006), and others may have been lost or discarded.

The Zoological Society of London's copy of Hodgson's painting of $O$. rostrata shows characters of both Alpine and Himalayan Forest Thrush in equal proportions, and does not appear to have been painted from $\mathrm{BMNH}$ 1859.3.4.22, which differs in lower mandible color, wing pattern, shape of underparts markings, and claw color. The painting is not marked in any way that links it to any individual specimen; nor is there a link in Hodgson's writings between specimen and painting. Characters given in Hodgson's description apply equally well to both specimens and do not serve to distinguish them in any way.

Because the selected specimen has long been considered the type of rostrata, because we have found no firm evidence that it was not part of the type series of rostrata, because it is unclear whether any specimens of the Himalayan Forest Thrush were available to Hodgson for description in 1845, because characters given by Hodgson in his description other than measurements (which could in any case have been taken differently from ours) and his accompanying illustration do not clearly indicate which taxon was being named, and because it is likely that syntypes were involved, we hereby unambiguously fix the meaning of rostrata by lectotypification under Recommendation 73.F of the ICZN (1999):

Oreocincla rostrata Hodgson, Ann. Mag. Nat. Hist. 15: 326. 1845. Lectotype, designated herein, is BMNH 1843.1.13.636. Nepal. This designation maintains the conventional application of $O$. rostrata Hodgson as a synonym of T. mollissimus Blyth, 1842.

\section{The identity of Turdus hodgsonii von Homeyer, 1849}

The name Turdus hodgsonii von Homeyer, 1849 was treated as a synonym of mollissima by Horsfield and Moore (1854), Jerdon (1862), Gray and Gray (1863) and Seebohm et al. (1898), in which it was spelled hodgsoni) among others. However, Bonaparte (1850) listed it, with question marks, along with mollissima and some of its other synonyms under Mistle Thrush Turdus viscivorus. Jerdon (1872), while keeping mollissima separate, kept T. hodgsoni Lafresnaye [sic] as a synonym of T. viscivorus (presumably simply following Bonaparte), and though the mistake was corrected by Cabanis (1860) and reiterated by Seebohm et al. (1898), subsequently T. hodgsonii has often been considered to be a synonym of $T$. viscivorus, not T. mollissima.

In May 2013 and again in May 2015, P.C.R. examined and measured the type specimen of $T$. hodgsonii von Homeyer, 1849 in ZMB (ZMB 3572), where it had been sent by Hodgson from the "Himalaya" (www.zoonomen. net/cit/RI/SP/Turd/turd00508a.jpg). On the basis of plumage and measurements (Figs. 2, 3), there is no doubt that $T$. hodgsonii is a synonym of the Alpine Thrush $Z$. mollissima s.s. Furthermore, even if the identity of ZMB 3572 as von Homeyer's type were questionable (which we have no reason to suspect), von Homeyer's (1849) very thorough description (in Gothic script German) makes it clear that the bird he was describing was a member of the mollissima group, as he describes the prominent blackand-white wing stripe and the crescent-shaped ("halbmondformig" or half-moon) flank markings, characters not present in viscivorus.

\section{The identity of Turdus oreocincloides Hodgson in Gray, 1844}

Another name that has been applied to and synonymized with $Z$. mollissima and therefore is a potential candidate as an available name of the Himalayan Forest Thrush is Turdus oreocincloides, Hodgson in J. E. Gray, 1844. A specimen in the BMNH collection was listed as the type of T. oreocincloides by Seebohm (1881) but this name is a nomen nudum (Warren and Harrison 1971) (www. nhm.ac.uk/research-curation/scientific-resources/collections/zoological-collections/bird-type-specimens), latter accessed 25 March 2014), and thus unavailable. The association of this specimen with one of Hodgson's drawings does not make the name available because the drawings are unpublished (Dickinson 2004). Given the uncertainties and complexities involving Hodgson's names and associated specimens, including their provenance and identity (Dickinson 2006), we choose not to make the name oreocincloides available by publishing a description, and in any case the specimen in question (BMNH 1880.1.1.373, erroneously labelled as BMNH 1880.1.1.372 
but corrected as per registration details; Robert PrŷsJones, in litt. 26 Mar 2014) is an unambiguous Himalayan Alpine Thrush Z. mollissima s.s. (Figs. 2, 3).

Yet another name that has been listed under the synonymy of Z. mollissima, Turdus micropus Hodgson in J. E. Gray, 1844, is listed as a junior synonym of Pied Groundthrush Zoothera wardii and as present at the BMNH by Seebohm (1881). However, the specimen was not listed or commented on by Warren and Harrison (1971) and its whereabouts are presently unknown (Robert Prŷs-Jones, pers. obs. 27 Mar 2014), but we assume that Seebohm (1881) was correct in placing it in the synonymy of $Z$. wardii.

Received: 30 October 2015 Accepted: 4 January 2016

Published online: 20 January 2016

\section{References}

Blyth E. Notes on various Indian and Malayan birds, with descriptions of some presumed new species. J Asiat Soc Bengal. 1842;11:160-95.

Bonaparte C-L. Conspectus generum avium, vol. 1. Brill: Leyden; 1850. Cabanis J. Eine neue Drossel-Gattung, Psophocichla. J f Orn. 1860;181-3.

Clement P, Hathway R, Wilczur J. Thrushes. Helm identification guides. London: Christopher Helm; 2000.

Collar N. Family Turdidae (Thrushes). In: del Hoyo J, Elliott A, Christie D, editors. Handb. birds world, vol. 10. Barcelona: Lynx Edicions; 2005. p. 514-807.

Delacour J. On the birds collected during the fifth expedition to French IndoChina. Ibis. 1930;6(12):564-99.

Dickinson EC. Systematic notes on Asian birds. 46. "A Catalogue of the Birds in the Museum of the Hon. East-India Company" by Horsfield \& Moore. Zool Verh. 2004;350:149-65.

Dickinson EC. Systematic notes on Asian birds. 52. An introduction to the bird collections of Brian Houghton Hodgson (1801-1894). Zool Meded. 2006:80:125-36.

Dickinson EC, Christidis L. The Howard \& Moore complete checklist of the birds of the world: Passerines, vol. 2. 4th ed. London: Aves Press; 2014.

Dickinson EC, Walters M. Systematic notes on Asian birds. 53. The authorship and date of publication of the "Catalogue of the Specimens and Drawings of Mammalia and Birds of Nepal and Thibet presented by B.H. Hodgson, Esq. to the British Museum". Zool Meded. 2006;80:137-53.

Drummond AJ, Ho SYW, Phillips MJ, Rambaut A. Relaxed phylogenetics and dating with confidence. PLoS Biol. 2006;4:e88. doi:10.1371/journal. pbio.0040088.

Drummond AJ, Suchard MA, Xie D, Rambaut A. Bayesian phylogenetics with BEAUti and the BEAST 1.7. Mol Biol Evol. 2012;29:1969-73. doi:10.1093/ molbev/mss075.

Fregin S, Haase M, Olsson U, Alström P. Pitfalls in comparisons of genetic distances: a case study of the avian family Acrocephalidae. Mol Phylogenet Evol. 2012;62:319-28. doi:10.1016/j.ympev.2011.10.003.

Gill F, Donsker D. IOC world bird list (v 5.3); 2015. http://www.worldbirdnames. org. (Accessed 1 Sep 2015). doi:10.14344/IOC.ML.5.4.

Gray J, Gray G. Catalogue of the specimens and drawings of mammals, birds, reptiles and fishes of Nepal and Tibet, presented by BH Hodgson, Esq., to the British Museum. 2nd ed. London: Trustees; 1863.

Greenoak F. British birds: their folklore, names and literature. London: Christopher Helm; 1997.

Gu X, Fu Y, Li W. Maximum likelihood estimation of the heterogeneity of substitution rate among nucleotide sites. Mol Biol Evol. 1995;12:546-57.

Hasegawa M, Kishino H, Yano T. Dating of the human-ape splitting by a molecular clock of mitochondrial DNA. J Mol Evol. 1985;22:160-74. doi:10.1007/BF02101694.
Heled J, Drummond AJ. Bayesian inference of species trees from multilocus data. Mol Biol Evol. 2010:27:570-80. doi:10.1093/molbev/msp274.

Hodgson B. Characters of six new species of Nepalese Birds. Ann Mag Nat Hist. 1845;15:326-7.

Horsfield T, Moore F. A catalogue of the birds in the Museum of the Hon. EastIndia Company, vol 1. London: Wm. H. Allen and Co.; 1854. p. i-XX, 1-451.

Huelsenbeck J, Ronquist F. MRBAYES: Bayesian inference of phylogenetic trees. Bioinformatics. 2001;17:754-5.

International Commission of Zoological Nomenclature. International code of zoological nomenclature, 4th ed. London: International Trust for Zoological Nomenclature; 1999. http://iczn.org/iczn/index.jsp. (Accessed 28 Mar 2014).

International Commission on Zoological Nomenclature (2012) Amendment of Articles 8, 9, 10, 21 and 78 of the International Code of Zoological Nomenclature to expand and refine methods of publication. Zootaxa 3450: 1-7.

Irestedt M, Ohlson J, Zuccon D. Nuclear DNA from old collections of avian study skins reveals the evolutionary history of the Old World suboscines (Aves, Passeriformes). Zool Scr. 2006;35:567-80.

Jerdon T. The birds of India, vol. 1. Calcutta: Military Orphan Press; 1862

Jerdon TC. XV.-Supplementary notes to "The Birds of India", part 2. Ibis. 1872;14(2):114-39. doi:10.1111/j.1474-919X.1872.tb06138.x.

Klicka J, Voelker G, Spellman G. A molecular phylogenetic analysis of the "true thrushes" (Aves: Turdinae). Mol Phylogenet Evol. 2005;34:486-500.

Lanfear R, Calcott B, Ho SYW, Guindon S. Partitionfinder: combined selection of partitioning schemes and substitution models for phylogenetic analyses. Mol Biol Evol. 2012;29:1695-701. doi:10.1093/molbev/mss020.

Munsell Color. Munsell soil color charts, revised edition. Grand Rapids, MI: Munsell Color; 2000.

Nylander J, Olsson U, Alström P., Sanmartín I. Accounting for phylogenetic uncertainty in biogeography: a Bayesian approach to dispersal-vicariance analysis of the thrushes (Aves: Turdus). Syst Biol. 2008;57:257-68.

Nylander JAA, Ronquist F, Huelsenbeck JP, Nieves-Aldrey JL. Bayesian phylogenetic analysis of combined data. Syst Biol. 2004;53:47-67.

Olsson U, Alström P. Molecular evidence suggests that the enigmatic Sulawesi endemic Geomalia heinrichi belongs in the genus Zoothera (Turdidae, Aves). Chin Birds. 2013:4:155-60.

R Core Team. A language and environment for statistical computing. Vienna: R Foundation for Statistical Computing; 2015. doi:10.1007/978-3-54074686-7. http://www.R-project.org.

Rambaut A. Figtree 1.4.0; 2002. http://tree.bio.ed.ac.uk/software/figtree/.

Rambaut A, Suchard M, Xie D, Drummond A. Tracer v1.6; 2014. http://beast.bio. ed.ac.uk/Tracer.

Rasmussen P, Anderton J. Birds of south Asia: the Ripley guide, vol. 2. Washington, DC: Smithsonian Institution; 2005.

Ripley SD. The subfamily Turdinae, thrushes. In: Mayr E, Paynter RAJ, editors. Check-list of birds of the world, vol. 10. Cambridge: Harvard; 1964. p. $13-228$.

Ronquist F, Huelsenbeck J. MrBayes 3: Bayesian phylogenetic inference under mixed models. Bioinformatics. 2003;19:1572-4.

Sclater WL. VI.-On the Indian Museum and its collection of birds. Ibis. 1892;6(4):65-87. doi:10.1111/j.1474-919X.1892.tb01187.x.

Seebohm H. Catalogue of the Passeriformes, or perching birds, in the collection of the British Museum. Cichlomorphae: part II. Containing the Family Turdidae (Warblers and Thrushes). London: British Museum of Natural History; 1881.

Seebohm H, Keulemans J, Sharpe R. Monograph of the Turdidae, or family of thrushes. London: Henry Sotheran \& Co.; 1898.

Sharpe R. History of the collections contained in the natural history departments of the British Museum. 2. Birds. London: Trustees; 1906.

Smithe FB. Naturalist's color guide. New York: American Museum of Natural History; 1975

Tamura K, Stecher G, Peterson D, et al. MEGA6: molecular evolutionary genetics analysis version 6.0. Mol Biol Evol. 2013;30:2725-9.

Vaurie C. Systematic notes on Palearctic birds. No. 13, Zoothera mollissima and Zoothera dixoni. Am. Museum novitates. No. 1706; 1955.

Voelker G, Outlaw R. Establishing a perimeter position: speciation around the Indian Ocean Basin. J Evol Biol. 2008;21:1779-88.

von Homeyer E. Uber die Gattung Turdus. Rhea. 1849;2:144-59. 
Warren R, Harrison C. Type-specimens of birds in The Natural History Museum [formerly British Museum (Natural History)], vol 2. Passerines; 1971. http:// www.nhm.ac.uk/research-curation/scientific-resources/collections/ zoological-collections/bird-type-specimens. (Accessed 25 Mar 2014).

Weir JT, Schluter D. Calibrating the avian molecular clock. Mol Ecol. 2008;17:2321-8. doi:10.1111/j.1365-294X.2008.03742.x.
Yang Z. Maximum likelihood phylogenetic estimation from DNA sequences with variable rates over sites: approximate methods. J Mol Evol. 1994;39:306-14. doi:10.1007/BF00160154.
Submit your next manuscript to BioMed Central and we will help you at every step:

- We accept pre-submission inquiries

- Our selector tool helps you to find the most relevant journal

- We provide round the clock customer support

- Convenient online submission

- Thorough peer review

- Inclusion in PubMed and all major indexing services

- Maximum visibility for your research

Submit your manuscript at www.biomedcentral.com/submit
() Biomed Central 